\title{
DOE/CE/28301-TH
}

\section{ENVIRONMENTAL EXTERNALITIES:}

\section{A SURVEY OF}

\section{STATE COMMISSION ACTIONS}

\section{July 11, 1990}

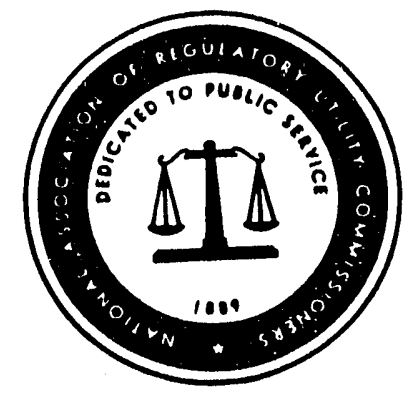

\section{National Association of Regulatory Utility Commissioners Room 1102 ICC Building; P.O. Box 684 Washington, D.C. 20044}

\section{Telephone No. (202) 898-2200}

Price $\$ 17.00$ 


\title{
A Survey of State PUC Activities to \\ Incorporate Environmental Externalities into \\ Electric Utility Planning and Regulation
}

May 1990

\author{
Prepared By: \\ S.D. Cohen, J.H. Eto, C.A. Goldman ${ }^{1}$ \\ J. Beldock ${ }^{2}$, and G. Crandall ${ }^{3}$ \\ National Association of \\ Regulatory Utility Commissioners \\ Room 1102 ICC Building; P.O. Box 684 \\ Washington, D.C. 20044 \\ Telephone No. (202) 898-2200
}

THIS DOCUMENT WAS PREPARED BY THE LAWRENCE BERKELEY LABORATORY (LBL) IN BERKELEY, CALIFORNIA. THROUGHOUT THE PREPARATION PROCESS THE MEMBERS OF THE NARUC COMMITTEE/STAFF SUBCOMMITTEE ON ENERGY CONSERVATION PROVIDED LBL WITH EDITORIAL COMMENTS AND SUGGESTIONS. THE VIEWS AND OPINIONS EXPRESSED HEREDN ARE STRICTLY THOSE OF THE AUTHORS AND MAY NOT AGREE WTTH OPINIONS AND POSITIONS OF THE NARUC OR THOSE OF THE U.S. DEPARTMENT OF ENERGY.

1. Lawrence Berkeley Laboratory, University of Califomia, Berkeley, CA

2. U.S. Department of Energy, Office of Building and Community Systemn, Washington, DC.

MASTER

3. Former chairman National Association of Regulatory Utility Commissioners, Energy Conservation Staff Committee; currently with MSB Associates, Middleton, WI. 


\section{Dear Fallow Commissioner:}

I hope you will take the time to review this survey of what state utility commissions are dolng to incorporate environmental externalities into the regulatory : process.

The NARUC Energy Conservation Committee asked Lawrence Berkeley Laboratory to undertake this survey and wishes to express its deep appreciation for the work done by Lawrence Berkeley Laboratory. The Energy Conservation Comittee with the assistance of the Department of Energy also initiated a conference on environmental externalities in New Ergland in 1989 and will sponsor a nationwide conference in Jackson Hole, Wyoming October 1-3, 1990.

Efforts by commisslons to address environmental externalities are escalating rapidly as national attention has focused on acid rain legislation and possible strategies for dealing with the threat of global warming. This survey provides a useful snapshot of this first wave of commission initiatives;.

sincerely,

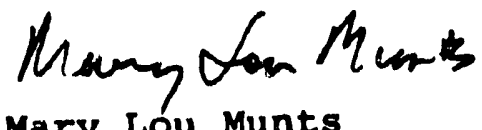

Mary Lou Munts

Commissioner

MLM : rmv06189002 . RMV/LETTER . CO 


\section{Table of Contents}

Executive Summary $\quad$ iii

$\begin{array}{ll}\text { Introduction } & 1\end{array}$

$\begin{array}{ll}\text { Approach } & 2\end{array}$

$\begin{array}{ll}\text { Summary of PUC Activities } & 4\end{array}$

$\begin{array}{ll}\text { Approaches for Incorporating Environmental Externalities } & 8\end{array}$

$\begin{array}{ll}\text { PUC Research Needs } & 14\end{array}$

$\begin{array}{ll}\text { Discussion } & 14\end{array}$

$\begin{array}{ll}\text { Conclusion } & 17\end{array}$

$\begin{array}{ll}\text { Acknowledgement } & 17\end{array}$

$\begin{array}{lr}\text { References } & 18\end{array}$

Appendix A: Summary of State PUC Survey $\quad$ A-1

Appendix B: Telephone Survey Questionaire $\quad$ B-1

DISCLAIMER

This report was prepared as an account of work sponsored by an agency of the United States Government. Neither the United States Government nor any agency thereof, nor any of their employees, makes any warranty, express or implied, or assumes any legal liability or responsibility for the accuracy, completeness, or usefulness of any information, apparatus, product, or process disclosed, or represents that its use would not infringe privately owned rights. Reference herein to any specific commercial produot, process, or service by trade name, trademark, manufacturer, or otherwise does not necessarily constitute or imply its endorsement, recommendation, or favoring by the United States Government or any agency thereof. The views and opinions of authors expressed herein do not necessarily state or reflect those of the United States Government or any agency thereof. 


\section{List of Tables}

Table 1 Criteria for Assessing the Status of PUC Activities 3

$\begin{array}{ll}\text { Table } 2 \text { Status of PUC Activities } & 6\end{array}$

$\begin{array}{ll}\text { Table } 3 \text { New York Bidding Credits } & 13\end{array}$

Table 4 Colorado QF Bidding Fuel Type Credits ' 13

$\begin{array}{lll}\text { Table } 5 \text { PUC Research Needs } & 15\end{array}$

\section{List of Figures}

Figure 1 Status of State Commission Activities $\quad 5$

Figure 2 Approach to Incorporating Environmental Externalities 9 


\section{Executive Summary}

Awareness of the environmental consequences of electricity production have led many state public utility commissions (PUC) to consider these externalities formally in their regulation of utilities. At the request of NARUC's Energy Conservation staff subcommittee, the Lawrence Berkeley Laboratory (LBL) conducted a survey to identify the extent and range of PUC approaches to this issue; responses were obtained from PUC staff in 49 states and the District of Columbia. The study should be viewed as providing a "snapshot" of regulatory developments in an area that is evolving rapidly.

We found that 17 PUCs had adopted explicit rules directing that these externalities be inccrporated. Among this group of states, most PUCs mandated that utilities consider environmental externality costs in resource planning and/or acquisition processes, which is typically done in one of three ways. The first approach relies on qualitative treatment by the utility during the resource planning process. A second approach involves use of a percentage adder that either increases the cost of supply resources or decreases the cost of DSM resources in the utility's planning process. A third approach involves direct quantification of the cost of the externality, which often occurs if the utility is developing a competitive resource procurement process (i.e., bidding). Several PUCs have also adopted approaches that implicitly incorporate externalities into the ratemaking process by permitting higher rates of return for resource alternatives that are environmentally benign. Connecticut allows up to an extra $5 \%$ rate of return for demand-side management while Kansas allows an extra $0.5-2.0 \%$ rate of return; a key rationale given for these higher rates of return is the perceived environmental benefits of DSM relative to supplyside technologies. These approaches are not mutually exclusive as several states have adopted several of these methods.

We also found that PUCs were extremely interested in obtaining better information to quantify the costs of environmental externalities, in understanding what other states had done, potentially through regional workshops, and in local or regional studies. 


\section{Introduction}

The environmental effects that accompany operation of electric generating plants have significant impacts on society. In 1985, electricity production from fossil-fired facilities accounted for about two-thirds of the $\mathrm{SO}_{2}$ and about one-third of the $\mathrm{NO}_{\mathrm{x}}$ and $\mathrm{CO}_{2}$ emitted in the U.S (Zimmerman et al., 1988; NPAP, 1987). ${ }^{1} \mathrm{SO}_{2}$ and $\mathrm{NO}_{x}$ are precursors to acid rain, which causes serious damage to forests, lakes, and agriculture. In addition, many electric supply options cause water pollution and land contamination, even after complying with current state and federal environmental regulations. Damage costs from water and land environmental impacts appear to be much less than damage estimates caused by air pollutants, but are still quite significant.

Partly in response to increased public concern about the impacts of acid rain and global climate change, regulatory commissions in many states are now grappling with difficult questions of how to include environmental externalities in utility resource planning. It is also clear that concem about the environmental costs of electricity generation is one of the driving forces for many Public Utility Commissions (PUC) in placing increased emphasis on demand reduction alternatives for utilities.

In order to determine current activities, interest, and information needs related to incorporating environmental concerns, the Energy Conservation Committee of the National Association of Regulatory Commissioners (NARUC) worked with Lawrence Berkeley Laboratory (LBL) and staff at the Michigan Public Service Commission in surveying state PUCs. LBL conducted a telephone and mail survey of PUCs which investigated the role of environmental externalities in utility resource planning and ratemaking. The survey focused on PUC activities, although respondents also reported on the role and efforts of other state agencies in many cases. We also asked PUC staf? 10 identify and prioritize important research activities or needs in this area.

Current federal and state regulations fall short of total mitigation of the environmental effects associated with generation of electric power. Thus, there are residual effects on the environment after power projects have complied with existing regulations. Environmental damages caused by power plants which are not paid for by the utility impose costs on society, leading to the classic economic problem of externalities. In this study, we report on approaches adopted by PUCs that go beyond existing federal and state minimum environmental standards for siting and operation of electric generation resources. It should be noted that PUCs often start from a different baseline in terms of residual environmental effects that are not internalized in power plant costs, because some states have adopted more comprehensive or stricter environmental protection legislation than others.

This survey represents a snapshot of current practices in a rapidly changing area. There is a wide range of awareness of this subject by PUCs and it appears that, to some extent, PUCs have proceeded independently of one another. This report is organized in several sections following

1 In 1985, U.S. electric utilities contributed about 16.2 tons of $\mathrm{SO}_{2}$ out of the nation's 23.7 tons and 6.9 tons of $\mathrm{NO}_{\mathrm{x}}$ out of 21 tons nationally. 
this introduction. In the next section, we summarize the survey questions and the approach we used to analyze PUC responses. Section 3 summarizes the results of the survey, which are reported in detail for each state in Appendix A. We then discuss limitations in the study, given the scope, available resources and time frame, and identify areas for future work.

\section{Approach}

In this section, we describe the methods used to assess the status of PUC activities and research needs identified by PUCs.

\section{Administration of the Survey}

The survey was conducted in three phases. First, telephone interviews were conducted based on a list of PUC contacts (typically, one per PUC) provided by NARUC's Energy Conservation Committee. Forty-nine PUCs were contacted through this process. ${ }^{2}$ Second, the results of these interviews were summarized under four general headings and the written results were sent to the respondents for confirmation, expansion and correction. We received responses on the written summaries from 35 PUCs. In the third phase, we inailed the compiled state information to the PUC chairman in each state. Twenty PUCs responded with further changes to the summary of activity in their states. Appendix A contains a written summary for each PUC along with the name(s) of the respondent.

\section{Organization of Survey Responses}

The initial phone survey relied on an extensive list of questions (see Appendix B). Responses to these questions were then grouped into four general categories:

1. Definition and role of environmental externalities in planning or ratemaking by the PUCs or other state agencies;

2. Roles of utility regulatory agencies in state utility regulation and resource planning;

3. Supply/demand balance, and;

4. Resource planning and acquisition.

The first category is a key element of the survey and includes information on existing or prospective state PUC and utility plans to incorporate environmental externalities in resource planning and selection.

The second category attempts to identify the boundary of PUC regulation. These boundaries are not fixed across states and the narrow goal of our survey was to identify public utility commission activities to incorporate environmental externalities. To the extent that other state agencies play a role in utility planning and regulation with respect to the incorporation of these

2 We were unable to contact a representative from the Montana PSC. 
externalities, we attempted to identify these agencies and their roles. We do not believe our efforts were entirely successful, given the scope and time frame of the study (see Discussion).

The third category places PUC activities on environmental externalities contextually in the overall utility planning environment. Significant activity to consider environmental externalities in states planning major capacity additions will have greater near-term consequences than would these same activities if they took place in states without current plans to build new capacity.

The fourth category links PUC activities that consider environmental externalities with the existing resource planning and selection processes in the states. What exactly is the PUC's authority with respect to resource planning and acquisition? Has the state adopted a competitive bidding or resource procurement process to select new resources? The absence of a clearly defined role in this process might render moot PUC activities to deal with environmental externalities. These linkages are sometimes articulated in the context of least-cost planning legislation or PUC rulemakings.

\section{Assessing the Status of PUC Activities}

Based on analysis of responses from individual PUCs, we grouped PUC activities in this area into four categories (see Table 1). These categories provide a relative index of the current status of state efforts to consider environmental externalities in resource planning and selection. However, they should be interpreted with caution, given the limitations of the survey and the rapid changes currently underway in a number of states.

Table 1 - Criteria for Assessing the Status of PUC Activities

\begin{tabular}{|cl|}
\hline Category & \multicolumn{1}{c|}{ Definition } \\
\hline O & Operational - approaches developed or rules passed \\
D & Developing - not yet implemented or failed to pass \\
A & Awareness - but no formal procedures \\
N & None - not aware of any efforts by PUC to include \\
& environmental concerns \\
\hline
\end{tabular}

\section{PUC Information Needs}

A second objective of the survey was to determine what types of information would be most useful to PUCs on environmental externalities as well as ways that this information could be communicated. 
These interests were divided into eight areas:

1. General or overview;

2. Information on resource impacts;

3. Methods for quantification of impacts;

4. Policy development or implementation strategies;

5. Legal aspects, and;

6. Experience of other states;

7. National or regional workshops;

8. Local area or regional case studies.

\section{Summary of PUC Activities}

PUC activities to incorporate environmental concerns into utility planning and regulation are evolving rapidly (see Appendix A for a summary of each PUC's response). For example, the situation in a rumber of states changed significantly during the five month period during which this survey was conducted. Figure 1 presents our assessment of the status of PUC and utility activities as of April 1990 for each state with respect to consideration of environmental externalities. Table 2 shows this information along with PUC perceptions of generating capacity needs over the next ten years, and a description of the methods used to incorporate environmental factors in states with operational approachs. PUCs or utilities in 17 states have adopted rules or policies in this area (status = "Operational"). Even in those states that we have categorized as having operational approaches, experience is relatively limited and major resource acquisition decisions by utilities are some years off in several states. In eight of these states, PUCs or utilities have developed quantification procedures for including environmental costs in resource planning and/or acquisition processes (e.g., California, Colorado, Massachusetts, New York, New Jersey, Oregon, Vermont, and Wisconsin). These efforts have increased significance in those states where utilities are proposing to or have actually begun the process of acquiring additional electric resources in the near term (e.g., New York, New Jersey, and Wisconsin), tecause the adopted rules will have a direct affect on the selection of resource options.

The stirvey revealed that PUCs in seven states were in the process of developing strategies to incorporate externalities or had tried unsuccessfully to do so in the past (status = "Developing").

The remaining 24 PUCs were classified in two other categories: "Awareness," which was assigned in situations in which either limited awareness and progress had been made or was expected, or, "None" - not aware of any efforts by the PUC to include environmental concerns. For these states, it is interesting to note that 16 expect to need either peak or base capacity within the next ten years. Moreover, of these 16, at least eight currently obtain more than $50 \%$ of their electricity from coal (Alabama, Delaware, Georgia, Indiana, Missouri, North Dakota, South Dakota, and West Virginia). These states already face potentially large compliance costs with 


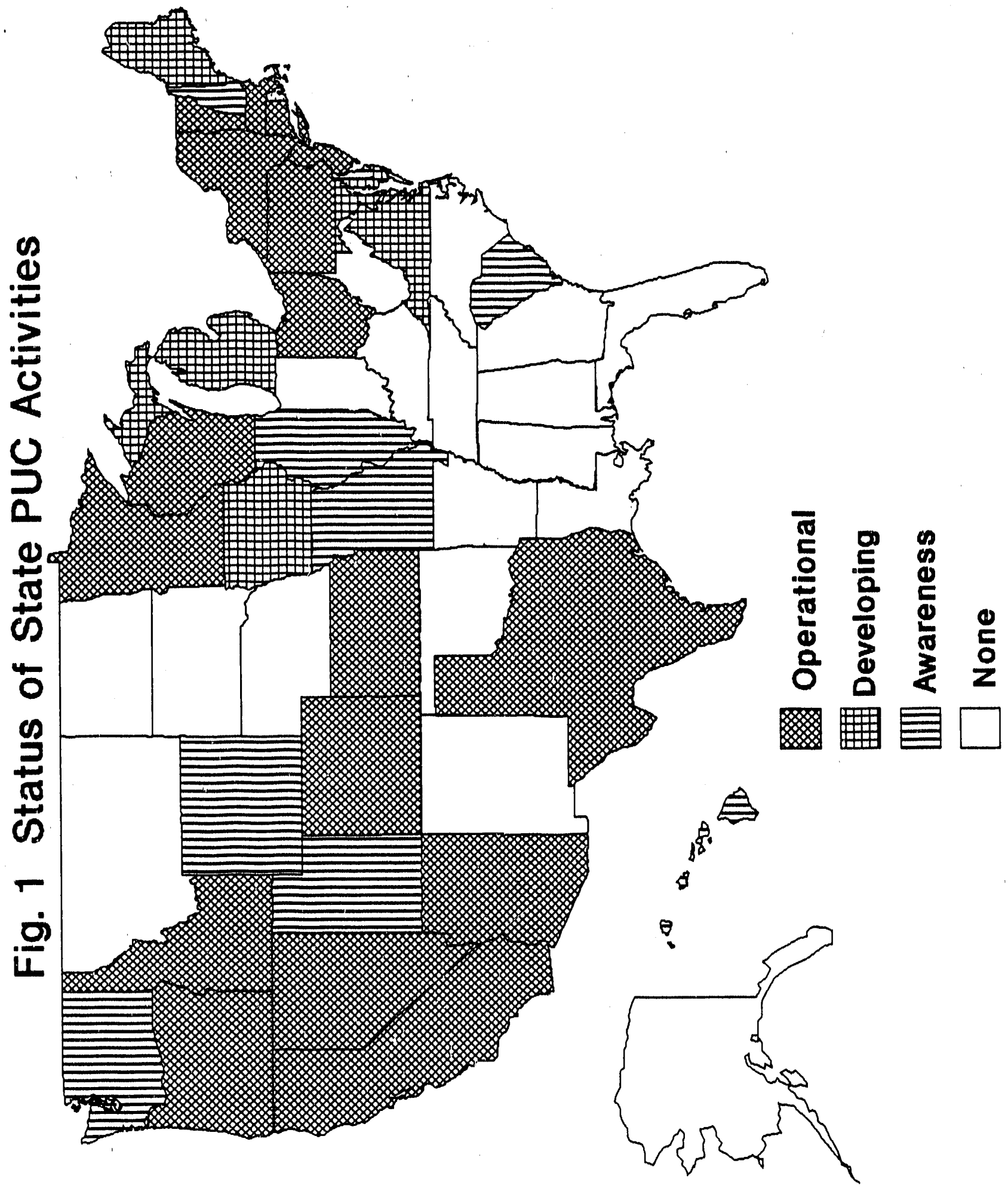


Table 2 - Status of PUC Activities

\begin{tabular}{|l|c|c|l|}
\hline \multicolumn{4}{|c|}{$\begin{array}{c}\text { Anticipated } \\
\text { Capacity Needed } \\
\text { Within 10 Years }\end{array}$} \\
State & Status ${ }^{2}$ & $\begin{array}{l}\text { Approach to } \\
\text { Externalities }\end{array}$ \\
\hline Alabama & P & N & \\
\hline Alaska & P & N & \\
\hline Arizona & P & O & Qualitative \\
\hline Arkansas & N & N & \\
\hline California & P & O & Env. adder to bidding system \\
\hline Colorado & P & O & QF bid evaluation \\
\hline Connecticut & N & O & Higher ROR, qualitative \\
\hline Delaware & B,P & A & \\
\hline District of Columbia & B,P & D & \\
\hline Florida & B,P & N & \\
\hline Georgia & B,P & N & \\
\hline Hawai: & B,P & A & \\
\hline Idaho & B,P & O & Unspecified higher ROR \\
\hline Illinois & B,P & A & \\
\hline Indiana & B,P & N & \\
\hline Iowa & P & D & \\
\hline Kansas & B,P & O & Higher ROR \\
\hline Kentucky & N & N & \\
\hline Louisiana & N & N & \\
\hline Maine & B,P & D & \\
\hline Maryland & B,P & D & \\
\hline Massachusetts & B,P & O & Bid evaluation \\
\hline Michigan & B & D & \\
\hline Minnesota & B,P & O & Qualitative \\
\hline Mississippi & N & N & \\
\hline
\end{tabular}

1. Anticipated Capacity Needed Within Ten Years:

$\mathrm{B}=$ Baseload, $\mathrm{P}=$ Peaking, $\mathrm{N}=$ Neither.

2. Status of State PUC Activities:

O Operational - approaches developed or rules passed

D Developing approaches - not implemented yet or failed to pass

A Awareness - but no formal procedures

N None - not aware of any efforts by PUC to include env. concerns 
Table 2 (cont.) - Status of PUC Activities

\begin{tabular}{|l|c|c|l|}
\hline \multicolumn{4}{|c|}{$\begin{array}{c}\text { Anticipated } \\
\text { Capacity Needed } \\
\text { Within Ten Years }\end{array}$} \\
State & Status ${ }^{2}$ & $\begin{array}{l}\text { Approach to } \\
\text { Incorporating } \\
\text { Externalities }\end{array}$ \\
\hline Missouri & P & A & \\
\hline Montana & & & \\
\hline Nebraska & & -- & \\
\hline Nevada & B,P & O & Qualitative \\
\hline New Hampshire & B,P & A & \\
\hline New Jersey & B,P & O & Bid evaluation \\
\hline New Mexico & N & N & \\
\hline New York & B,P & O & Bid evaluation \\
\hline North Carolina & P & N & \\
\hline North Dakota & P & N & \\
\hline Ohio & P,B & O & Qualitative \\
\hline Oklahoma & N & N & \\
\hline Oregon & B,P & O & Quantitative: resource planning \\
\hline Pennsylvania & P & O & Qualitative \\
\hline Rhode Island & B,P & D & \\
\hline South Carolina & P & A & \\
\hline South Dakota & B,P & N & \\
\hline Tennessee & & -- & \\
\hline Texas & N & O & Qualitative \\
\hline Utah & N & A & \\
\hline Vermont & B,P & O & 15\% adder \\
\hline Virginia & B,P & D & \\
\hline Washington & B & A & \\
\hline West Virginia & B,P & N & \\
\hline Wisconsin & P & O & 15\% adder, quantitative \\
\hline Wyoming & N & A & \\
\hline
\end{tabular}

1. Anticipated Capacity Need Within Ten Years:

$\mathrm{B}=$ Baseload, $\mathrm{P}=$ Peaking, $\mathrm{N}=$ Neither.

2. Status of State PUC Activities:

O Operational - approaches developed or rules passed

D Developing approaches - not implemented yet or failed to pass

A A wareness - but no formal procedures

N None - not aware of any efforts by PUC to include env. concerns

-- State PUC does not regulate generating utilities 
the passage of new federal clean air legislation and will need to carefully consider the environmental impacts of new resource additions.

Finally, we did not categorize the status of PUC efforts in two states (Nebraska and Tennessee). In Nebraska, all power generation is publicly owned and not under the jurisdiction of the PUC. Tennessee is similar, the vast majority of power is generated by the Tennessee Valley Authority.

\subsection{Approaches for Incorporating Environmental Externalities}

The survey results indicate that PUCs are exploring a broad range of methods to incorporate environmental concerns into utility resource planning. Overall, the approaches affected two general areas of utility regulation: resource planning and acquisition processes, and ratemaking. We identified three basic methods that have been used by states in the context of resource planning/acquisition:

Qualitative treatment during the resource planning process,

Direct quantification of environmental costs and impacts as part of integrated resource planning (e.g., alternate scenarios which explore implications of mandated emission reductions on a utility's resource plan) and/or competitive resource acquisition processes (e.g, evaluation of bids from independent power producers), typically through the assignment of a weight to environmental considerations in a scoring system,

$\square$ Use of a percentage adder/subtractor which is applied to the capital cost of supply or demand-side resources during the planning process.

In terms of ratemaking approaches, several states have increased their authorized rate of return (ROR) for demand-side management (DSM). As part of this process, PUCs estimate externality costs, which are then internalized in the economic costs of resource alternatives. The increased utility earnings for demand-side management (DSM) investments may raise average rates somewhat. Benefits that arise from DSM programs typically raise distributional issues that must be addressed by utilities and PUCs. Customers who participate in the DSM programs will have higher rates, but lower energy bills. Given current ratemaking in most states, nonparticipants will have higher rates and slightly higher bills in the near term because they do not directly receive program benefits. In the long run, cost-effective DSM programs benefit all customers because the costs of avoided new capacity and avoided energy consumption will lower the utility's projected revenue requirement compared to other resource options.

In contrast, environmental concerns incorporated in planning approaches are designed to influence the choice and relative magnitude of selected resources. It is also worth noting that the approaches are not mutually exclusive. For example, in Connecticut, the Department of Public Utility Control has authorized higher rate of return for utility investments in DSM and utilities have beel asked to evaluate environmental externalities qualitatively in their resource plans. 


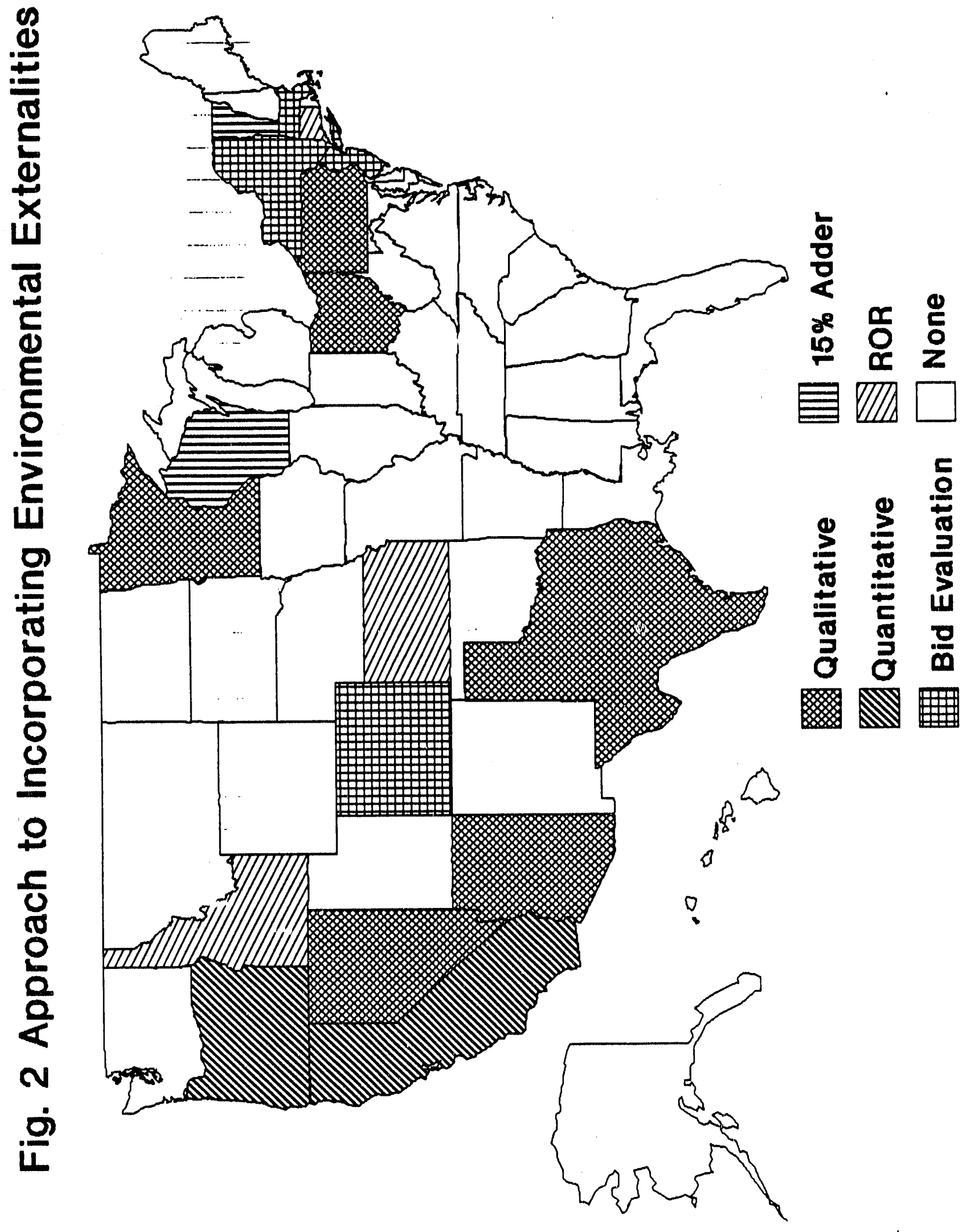




\section{Incorporating Environmental Concerns in Planning and Resource Acquisition Processes}

In this section, we describe the various methods being used to incorporate environmental considerations in utility resource planning in more detail by discussing examples from some of the more active states.

Qualitative treatment of environmental externalities has been adopted by PUCs in six states. For example:

Nevada - The state of Nevada has passed regulations that provide the commission with broad discretion to "give preference to the measures ... that provide the greatest economic and environmental benefits to the state." (Getto, et al., 1989.)

Arizona - The Arizona Corporation Commission (ACC) considers environmental externalities, such as sulfur oxide and carbon dioxide emissions, in its least cost planning activities. The Commission's rules do not specify a method by which such externalities must be considered.

Minnesota - In December 1989, the Public Utilities Commission proposed a resource planning rule that would incorporate environmental considerations. Additionally, in order to reduce the damage from acid rain, the legislature passed a bill in 1986 that caps sulfur dioxide emissions from the state's two main power plants.

Some states use a percentage adder that increases the cost of supply-side resources or decreases the cost of demand-side resources in the utility's planning process. Percentage adders that have been adopted by states thus far have generally been technology-based. A technology-based adder treats all projects using the same technology similarly. For example, a DSM option may be given a credit and allowed X percent higher cost in evaluating cost-effectiveness compared to supply-side resources. The principal advantage of technology-based percentage adiers is their relative simplicity and ease of implementation. Drawbacks are that they are less accurate for specific projects of the same technology type. In some cases, pollutant levels for a particular technology may differ significantly depending on the project's size and design characteristics (Koomey, 1990).

The Northwest Power Planning Council (NPPC) was the first entity to use this type of approach. NPPC is a regional energy planning body which was created by the Pacific Northwest Electric Power Planning and Conservation Act (1980). The Council occupies a unique role in the Northwest with statutory requirements to develop a regional least-cost plan that considers environmental quality and which includes a methodology for determining quantifiable environmental costs and benefits. NPPC has the the most influence on Bonneville Power Administration (BPA) resource acquisition policies and state PUCs in the region. NPPC applies a 10\% credit to conservation resources over traditional supply resources in its approach to resource planning. For example, if avoided costs are 5 cents/kWh (based on a proxy fossil fuel unit), all conservation that costs less than 5.5 cents/kWh is considered economical (NPPC, 1989).

Wisconsin - As part of Wisconsin's Advanced Plan filing, each utility is required to credit noncombustion technologies because of the impact of reduced air pollution. Thus, as utilities screen resource options in their least-cost planning process, non-fossil supply technologies and 
demand-side resources can cost $15 \%$ more than a combustion source and still be considered comparable in terms of overall societal costs (PSCW, 1989).

Vermont - in April 1990, the Public Service Board ruled that utilities should discount demandside resource costs by ten percent to reflect the "comparative risk and flexibility" advantages of such resources and that supply-side resources will be increased initially by five percent "to capture costs not already included in the monetized prices of supply sources" (Vt. PSB, 1990). Moreover, the Order initiates a rule-making proceeding to further define "adders to represent the cost of environmental externalities."

Maine - In 1988, legislation for a $20 \%$ adder failed to pass.

Methods that involve direct quantification of externality costs as part of resource planning and/or acquisition processes are increasingly being adopted by states. A number of utilities have implemented bidding systems in which environmental impacts of a bidder's project are evaluated explicitly in a weighting or point scheme. Examples of direct quantification approaches include:

California - Both the California Public Utility Commission (CPUC) and the California Energy Commission (CEC) currently have proceedings in which the treatment and quantification of environmental impacts are being considered. As part of its long term resource planning function, the CEC issues a biennial Electricity Report. For the 1990 Electricity Report (ER 90), the CEC staff has proposed that the dollar values of air pollution impacts be reflected in the CEC's resource plan (see Appendix A). The estimates would reflect the value of cutting emissions beyond that required under emission limits and is motivated in large part by air quality problems in the South Coast Air Quality Management District (SCAQMD). The dollar value placed on emissions would be based on the cost of control in the SCAQMD's Tier 1 efforts and represent average costs for a selected group of controls that offer major emission reductions (CEC Staff, 1989). The CEC staff position is being examined and reviewed by utilities and others in hearings and workshops; ultimately the CEC will adopt its recommended approach in the final Electricity Report. It is unclear how incorporation of these values into the CEC's forecast would ultimately affect which resources are built in California because the CPUC's bidding process is relatively independent (California Legislature Joint Committee on Energy Regulation and the Environment, 1990).

Simultaneously, the CPUC is considering how to quantify and incorporate environmental impacts into the CPUC's existing Standard Offer \#4 pricing methodology and bidding protocol for Qualified Facilities (CPUC, 1990). The CPUC held workshops on this topic in FebruaryMay 1990 and received comments from interested parties. The CPUC is considering using an adder to incorporate environmental concerns into electric resource planning and acquisition processes. Adders are payments in addition to the price paid for power to all winning bidders in the CPUC's bidding system, which uses a second-price auction.

Oregon - Unlike California, Oregon puts major responsibility on the utilities for developing environmental externality costs. In its April 1989 Least Cost Planning order, the Public Utility Commission required that external costs be considered in the cost-effectiveness evaluation of resource options and that both qualitative and quantitative approaches should be employed (Oregon PUC, 1989). Since external costs are uncertain and also subjective in many cases, the 
utilities are required to present these costs separately from conventional accounting costs and to give a range of expected values. This process of valuing environmental externalities is designed to be flexible and open to review. Pacific Power and Light (PP\&L) was the first utility to file a long-term integrated resource plan under the new order and addressed environmental extemalities in the following fashion: 1) the company included a scenario in its sensitivity analysis in which $\mathrm{CO}_{2}$ emissions from PP\&L's existing and new generating facilities would be reduced by $20 \%$ from 1988 levels by the year 2005 . Under this scenario, the utility found that it made sense to promote repowering of existing facilities and acquire more renewable resources compared to the basecase, and; 2) as a check on the robustness of the relative ranking of resources in individual scenarios, PP\&L added a combustion tax of $10 \mathrm{mills} / \mathrm{kWh}$ to the cost of fossil-fired resources and then analyzed the resulting mix of resources.

Wisconsin - The Wisconsin PSC has required that Wisconsin utilities include in their planning processes a "NEEDS" factor, which includes external environmental, social, and political costs that are "Not Easily Expressed in Dollars." As an initial step, the utilities must include a 15\% cost credit for planning options which do not involve combustion. The PSC has also directed the state's utilities to develop integrated resource plans which anticipate significant emission reductions for carbon dioxide (e.g., $20 \%$ by the year 2000).

New York - The New York Public Service Commission (NYPSC) has been overseeing the development of bidding programs to acquire new resources by the state's seven investor-owned utilities. Environmental impacts are explicitly included among the factors considered in selected winning bids. The NYPSC's Opinions that established guidelines for utility bidding programs articulated two key principles relating to environmental factors: 1) all pernittable projects are not environmentally equal and thus inferior projects should be penalized accordingly, and; 2) the weights for environmental factors relative to each other and relative to other non-environmental factors (e.g., price) should be based on the costs of mitigating the environmental impacts. Based on NYPSC staff analysis, the most environmentally disruptive source, under the most unfavorable circumstances, is assigned an environmental cost of $1.405 \mathrm{c} / \mathrm{kWh}$, which is about $24 \%$ of the utility's avoided cost. All other resources are assigned some fraction of that total, depending on their environmental point score (NYPSC, 1989). This scheme assigns point values to different levels of air and water emissions and land degradation (see Table 3).

New Jersey - New Jersey utilities are implementing integrated resource bidding programs based on a settlement agreement between utilities, QF representatives, and Board of Public Utilities staff. There are three categories in the bidding process: economic issues (maximum of 55\%), non-economic issues (minimum of 20\%), and project viability (minimum of 25\%) (PSE\&G, 1989). Non-economic issues include environmental issues and fuel efficiency. Environmental factors and energy efficiency were each weighted at one percent of the total bidding points by Public Service Electric \& Gas Company in its recent solicitation. Jersey Central Power \& Light Company's RFP released in June 1989 contained a weighting of up to $2 \%$ for reduced $\mathrm{NO}_{\mathrm{x}}$ emmissions and up to $4 \%$ for higher levels of fuel efficiency. 
Table 3 - New York Bidding Credits

\begin{tabular}{|ll|}
\hline Externality & $\begin{array}{c}\text { Mitigation Cost } \\
(\$ / \mathrm{kWh})\end{array}$ \\
\hline Air Emissions & \\
Sulfur Oxides & 0.25 \\
Nitrogen Oxides & 0.55 \\
Carbon Dioxides & 0.10 \\
Particulates & 0.005 \\
Water Impacts & 0.10 \\
Land Use & 0.40 \\
\hline Total & 1.405 \\
\hline
\end{tabular}

Colorado - Environmental and economic externalities are included in Colorado's QF bidding process. In 1988, the Colorado PUC approved biennial QF bidding for up to twenty percent of each utility's demand forecast. Bidding is done on a one hundred point scale. Zero to twelve points are given for fuel type (see Table 4). The fuel type points include environmental and economic externalities.

\section{Table 4 - Colorado QF Bidding \\ Fuel Type Credits}

\begin{tabular}{|l|r|}
\hline Fuel Type & Points \\
\hline Renewables & 12 \\
Coal & 5 \\
Natural Gas & 2 \\
Oil & 1 \\
\hline
\end{tabular}

Renewables are given an additional five point bonus at the end of the bidding process. (Colorado PUC, 1988). The bidding process has not yet been implemented because there is currently excess capacity; no QF bids are expected until the mid-1990s.

Northwest Power Planning Council - In developing the Council's 1990 Power Plan, the Council's Staff has recently prepared an issue paper which reviews environmental pollutants associated with various resource types and their major effects on the environment (NPPC, 1990).

\section{Incorporation of Environmental Externalities in Ratemaking}

A second use of environmental externalities involves some form of explicit quantification of the externality costs, which then allows for direct internalization into the economic cost of 
various resource alternatives. For example, ratemaking treatment of more environmentally benign resource alternatives that results in increased rates of return for these alternatives may raise the utility's revenue requirements. In contrast to the first use of environmental externalities in the planning process, these approaches internalize these externalities in the ratemaking process.

Implementation of this approach was found exclusively in the form of incentives designed to reward utilities for DSM activities. PUCs and utilities in a number of states are developing ratemaking mechanisms that encourage utility DSM programs in order to overcome barriers posed by traditional regulation. In some states, the perceived environmental benefits associated with DSM options are often cited as one of the rationales for these incentives. We included only those PUCs that made explicit reference to environmental externalities as the principal rationale for inclusion of utility incentives for DSM in Table 2. For example, Connecticut allows up to an extra $5 \%$ rate of return and Kansas allows an extra $0.5-2.0 \%$ rate of return. In Idaho, the PUC can give an unspecified higher rate of return to utilities that have demonstrated "aggressive" conservation programs.

\subsection{PUC Research Needs}

During the telephone survey the PUC's were also asked to identify leading research needs in the area of incorporating environmental externalities. Three major findings emerged:

1. PUCs expressed great interest in obtaining information that would allow for quantification of environmental externalities.

2. PUCs were very interested in participating in regional workshops to find out what other states were doing and to discuss approaches for treating environmental externalities.

3. Finally, PUCs expressed interest in local or regional studies to better understand the impacts of various approaches in terms of their regional characteristics and resource mix.

Results for each state are summarized in Table 5 .

\section{Discussion}

Our survey of state efforts to consider environmental externalities is subject to a number of important caveats. First, the survey relied almost exclusively on PUC staff and commissioners, and did not include other state agencies that may play a role in utility-related environmental considerations. PUC activities to incorporate environmental consideration in resource planning do not exhaust a given state's efforts to deal with these issues. PUC activities are affected by each commission's authorizing legislation as well as other state legislation that addresses environmental review processes or major environmental issues (e.g., acid rain deposition). For example, in California, two state agencies play a particularly active role in electric resource planning. Regulatory authority is split between the Public Utilities Commission and the Energy Commission (CEC), with the CEC having responsibility for siting of new power plants larger than 50 MW. The PUC is responsible for ratemaking and the resource acquisition process for 
Table 5. PUC Research Needs

\begin{tabular}{|c|c|c|c|c|c|c|c|c|}
\hline State & $\begin{array}{l}\text { over- } \\
\text { view }\end{array}$ & $\begin{array}{l}\text { resource } \\
\text { impact }\end{array}$ & $\begin{array}{l}\text { quanti- } \\
\text { fication }\end{array}$ & $\begin{array}{l}\text { policy } \\
\text { impl. }\end{array}$ & $\begin{array}{c}\text { legal } \\
\text { aspects }\end{array}$ & $\begin{array}{l}\text { other } \\
\text { states }\end{array}$ & $\begin{array}{l}\text { work- } \\
\text { shops }\end{array}$ & $\begin{array}{l}\text { local } \\
\text { studies }\end{array}$ \\
\hline Alabama & & & $x$ & $x$ & & & $x$ & $x$ \\
\hline Alaska & $x$ & $x$ & $x$ & $x$ & $x$ & $x$ & $x$ & $x$ \\
\hline Arizona & & & & & & $x$ & $x$ & $x$ \\
\hline Arkansas & $x$ & $x$ & $x$ & $x$ & $x$ & $x$ & $x$ & \\
\hline California & & $x$ & $x$ & $x$ & $x$ & $x$ & $x$ & $x$ \\
\hline Colorado & $\mathbf{x}$ & $x$ & $x$ & $x$ & $x$ & $x$ & $x$ & $\mathbf{x}$ \\
\hline Connecticut & & $x$ & $x$ & $x$ & $x$ & $x$ & $x$ & $\mathbf{x}$ \\
\hline Delaware & $x$ & & & & & $x$ & $x$ & $x$ \\
\hline $\begin{array}{l}\text { District } \\
\text { of Columbia }\end{array}$ & $\mathbf{x}$ & $x$ & $\mathbf{x}$ & $\mathbf{x}$ & $\mathbf{x}$ & $x$ & $\mathbf{x}$ & $\mathbf{x}$ \\
\hline Florida & & & $x$ & & & & $x$ & $x$ \\
\hline Georgia & $x$ & & $x$ & $x$ & & & $x$ & $x$ \\
\hline Hawaii & $x$ & $x$ & $x$ & $x$ & $x$ & $\mathbf{x}$ & & \\
\hline Idaho & & $x$ & & & & & & \\
\hline Illinois & $x$ & $x$ & $x$ & $x$ & $x$ & $x$ & $x$ & $x$ \\
\hline Indiana & $x$ & $x$ & & & & $\mathbf{x}$ & $x$ & $\mathbf{x}$ \\
\hline Iowa & $x$ & $x$ & $x$ & $x$ & $\mathbf{x}$ & $x$ & $\mathbf{x}$ & $\mathbf{x}$ \\
\hline Kansas & & & $x$ & $x$ & $x$ & $x$ & $x$ & $x$ \\
\hline Kentucky & $x$ & $x$ & $\mathbf{x}$ & $x$ & $x$ & $\mathbf{x}$ & $x$ & $\mathbf{x}$ \\
\hline Louisiana & $x$ & & & & & $x$ & & \\
\hline Maine & $x$ & $x$ & $x$ & $x$ & $x$ & $\mathbf{x}$ & $x$ & $x$ \\
\hline Maryland & & $x$ & $x$ & $x$ & $x$ & $x$ & $x$ & $x$ \\
\hline Massachusetts & & $x$ & $x$ & & & & $x$ & $x$ \\
\hline Michigan & $x$ & $\mathbf{x}$ & $\mathbf{x}$ & $x$ & & $\mathbf{x}$ & $x$ & $\mathbf{x}$ \\
\hline Minnesota & $x$ & $x$ & $\mathbf{x}$ & $x$ & $\mathbf{x}$ & $x$ & $x$ & $x$ \\
\hline Mississippi & $x$ & & & & & $x$ & $x$ & $\mathbf{x}$ \\
\hline
\end{tabular}


Table 5 (cont.) PUC Research Needs

\begin{tabular}{|c|c|c|c|c|c|c|c|c|}
\hline State & $\begin{array}{l}\text { over- } \\
\text { view }\end{array}$ & $\begin{array}{l}\text { resource } \\
\text { impact }\end{array}$ & $\begin{array}{l}\text { quanti- } \\
\text { fication }\end{array}$ & $\begin{array}{l}\text { policy } \\
\text { impl. }\end{array}$ & $\begin{array}{c}\text { legal } \\
\text { aspects }\end{array}$ & $\begin{array}{l}\text { other } \\
\text { states }\end{array}$ & $\begin{array}{l}\text { work- } \\
\text { shops }\end{array}$ & $\begin{array}{c}\text { local } \\
\text { studies }\end{array}$ \\
\hline Mississippi & $x$ & & & & & $\mathbf{x}$ & $\mathbf{x}$ & $\mathbf{x}$ \\
\hline Missouri & $x$ & & & & & $\mathbf{x}$ & $x$ & \\
\hline \multicolumn{9}{|l|}{$\begin{array}{l}\text { Missouri } \\
\text { Montana }\end{array}$} \\
\hline Nebraska & & & & & & & & \\
\hline Nevada & $x$ & $x$ & $\mathbf{x}$ & $x$ & $\mathbf{x}$ & $\mathbf{x}$ & $x$ & $x$ \\
\hline New Hampshire & $x$ & $x$ & $x$ & $x$ & $\mathbf{x}$ & $\mathbf{x}$ & $x$ & $\mathbf{x}$ \\
\hline New Jersey & & & $\mathbf{x}$ & $\mathbf{x}$ & $x$ & $\mathbf{x}$ & $\mathbf{x}$ & $\mathbf{x}$ \\
\hline New Mexico & $\mathbf{x}$ & & & & $x$ & $x$ & & \\
\hline New York & & $x$ & $x$ & $\mathbf{x}$ & $\mathbf{x}$ & $x$ & $x$ & $x$ \\
\hline North Carolina & $x$ & $x$ & $x$ & $x$ & $x$ & $x$ & $x$ & $x$ \\
\hline North Dakota & & & & $x$ & & $x$ & $x$ & $\mathbf{x}$ \\
\hline Ohio & $\mathbf{x}$ & $x$ & $x$ & $\mathbf{x}$ & $x$ & $x$ & $x$ & $x$ \\
\hline Oklahoma & $x$ & & & & & $x$ & $x$ & \\
\hline Oregon & & & $x$ & & & $x$ & $\mathbf{x}$ & $x$ \\
\hline Pennsylvania & $x$ & $x$ & $\mathbf{x}$ & $x$ & $x$ & $x$ & $\mathbf{x}$ & $x$ \\
\hline Rhode Island & $x$ & $x$ & $x$ & $x$ & $\mathbf{x}$ & $x$ & $\mathbf{x}$ & $x$ \\
\hline South Carolina & $x$ & $x$ & $\mathbf{x}$ & $x$ & $\mathbf{x}$ & $\mathbf{x}$ & $x$ & $\mathbf{x}$ \\
\hline South Dakota & & & & & & $x$ & & \\
\hline Tennessee & & & & & & & & \\
\hline Texas & & & $x$ & & & $x$ & $x$ & $\mathrm{x}$ \\
\hline Utah & & & & & & $x$ & $x$ & \\
\hline Vermont & $x$ & $\mathbf{x}$ & $x$ & $\mathbf{x}$ & $\mathbf{x}$ & $x$ & $x$ & $\mathbf{x}$ \\
\hline Virginia & $\mathbf{x}$ & $x$ & & & $\mathbf{x}$ & & $\mathbf{x}$ & $x$ \\
\hline Washington & $x$ & $x$ & $\mathbf{x}$ & $\mathbf{x}$ & $x$ & $x$ & $x$ & $\mathbf{x}$ \\
\hline West Virginia & $\mathbf{x}$ & $x$ & $x$ & $\mathbf{x}$ & $x$ & $x$ & & \\
\hline Wisconsin & & & $x$ & $x$ & & $x$ & $\mathbf{x}$ & $x$ \\
\hline Wyoming & $x$ & $x$ & $x$ & & & $\bar{x}$ & $x$ & \\
\hline
\end{tabular}


private producers. We attempted to indicate the potential for significant non-PUC environmental externality activities in a given state by indicating the relative roles of PUCs and other state regulatory agencies in Appendix A. However, we were limited by the informaticn provided in the responses from PUC contacts.

Second, this study could be broadened by a more in-depth case study analysis of leading states that have developed approaches to incorporate environmental externalities in resource planning and acquisition; Ottinger, et al., (1990) performed such an analysis for five states.

Third, accurate assessments of PUC policies in the area of envirormental externalities may be difficult to determine through the statements of several individuals, particularly in large commissions. Moreover, respondents may not be aware of all relevant work within their PUCs or may not share a common vocabulary in characterizing certain practices as "incorporating environmental externalities."

Finally, we may have introduced biases of our own based on the fact that our prior knowledge or supplementary information about PUC activities varied among the states. We attempted to use all information available, but information was not available uniformly.

\section{Conclusion}

This study was based on a telephone and and mail survey of PUC staff in 49 states plus the the District of Columbia on PUC and utility efforts to incorporate environmental externalities in resource planning and selection processes. Ultimately, we received written confirmation of our state summaries from 42 PUCs (including the second and third phases). We found widely varying PUC levels of activity, including seventeen PUCs with procedures in place, although most are relatively untested. Among states with operational procedures, initial efforts typically focused on including environmental effects in the resource planning process (e.g., qualitative treatment or percentage adders). Recently, with the advent of competitive bidding processes, some PUCs and utilities have begun to incorporate environmental factors explicitly in the resource selection process. The most sophisticated approaches include explicit quantification of selected external environmental costs.

This survey should be viewed as a "snapshot" of regulatory developments in an area that is evolving rapidly. While we are confident in the accuracy of the information reported by PUC respondents, given the verification procedures, we did not fully assess, but attempted to note the existence of, the relative roles of other state agencies in incorporating environmental externalities.

Support for increased activities for research and workshops in this area was uniformly positive. We found that PUCs were extremely interested in obtaining better information to quantify the costs of environmental externalities, in understanding what other states had done, and in local or regional studies. These topics should be addressed in future work sponsored by DOE and other organizations.

\section{Acknowledgement}

The work described in this paper was funded by the Assistant Secretary for Conservation and Renewable Energy, Office of Utility Technologies of the U.S. Department of Energy under Contract No. DE-AC03-76SF00098. The authors would like to acknowledge the support and review comments of Jacob Kaminsky, Ken Schafer, ar:d Diane Pirkey in DOE's Office of Utility Technologies. 
We thank PUC staff in each state who responded to the telephone and mail surveys. A special thanks goes to Ron Callen of the Michigan PSC for his work on the survey. Richard Ottinger and staff from NARUC's Energy Conservation Committee made helpful comments on drafts of this report. We thank Sue Krouscup for assembling and preparing the final report.

\section{References}

1. California Energy Commission (CEC) Staff. Energy Facility Siting and Environmental Protection Division. November 1989. "Valuing Emission Reductions for Electricity Report 90." California Energy Commission, Staff Issue Paper \#3R, Docket \#88-ER-8.

2. California Public Utility Commission, April 13, 1990, Workshop Report: Incorporating Environmental Adders Into the Biennial Plan Update Proceeding," OII.89-04-007.

3. Colorado Prablic Utilities Commission (Colorado PUC). June 9, 1988. Decision No. C88726, "Application of the Public Service Company of Colorado Regarding Cogeneration and Small Power Production Projects, Application No. 38871."

4. Getto, Townsend et al. July 1989. "Nevada Senate Bill No. 497."

5. J. Koomey. March 1990. "Comparative Analysis of Monetary Estimates of External Costs Associated with Combustion of Fossil Fuels," Lawrence Berkeley Laboratory, LBL-28313.

6. National Acid Precipitation Assessment Program (NPAP). 1987. Interim Assessment, Vol. I.

7. New York Public Service Commission (NYPSC). April 12, 1989. "Opinion and Order Establishing Guidelines for Bidding Program." Case 88-E-241, Proceeding on Motion of the Commission (established in Opinion No. 88-15) as to the guidelines for bidding to meet future electric capacity needs of Orange and Rockland Utilities, Inc., Opinion 89-7.

8. Northwest Power Planning Council (NPPC). April 17, 1989. "Acronnting for the Environmental Consequences of Electricity Resources During the Power Planning Process." Issue Paper 89-7.

9. Northwest Power Planning Council. February 28, 1990. "New Resources: Supply Curves and Environmental Effects," Staff Issue Paper, 90-1.

10. Oregon Public Utility Commission (Oregon PUC). April 1989. "In the Matter of the Investigation into Least-Cost Planning for Resource Acquisitions by Energy Utilities in Oregon," Order No. 89-507.

11. R. Ottinger, N. Robinson, S. Babb, D. Wooley and D. Hodas. February 1990. "Environmental Costs of Electricity" (Draft final report cited with permission), Pace University Center for Environmental Legal Studies.

12. Pacific Northwest Electric Power Planning and Conservation Act, 1980. 16 U.S.C. 839.

13. Public Service Electric and Gas (PSE\&G). August 15, 1989. "Request for Proposals to Supply Electric Capacity and Energy," Newark, NJ.

14. Vermont Public Service Board (Vt PSB). April 1990. "Least Cost Investments, Energy Efficiency, Conservation and Management of Demand for Energy," Docket \#5270.

15. Wisconsin Public Service Commission (PSCW). April 6, 1989. "Findings to Fact, Conclusion of Law and Order, Advance Plan 5," Docket 05-EP-5. 
16. D. Zimmerman, W. Tax, M. Smith, J. Demmy, and R. Battye. November 1988. "Anthropogenic Emissions Data for the 1985 NAPAP Inventory." U.S. Environmental Protection Agency, EPA-600/7-88-022. 
Appendix A - Summary of State PUC Survey

A-1 


\section{State Commission Environmental Externality Survey - Alabama}

\section{1.) Definition and Role of Environmiental Externalities in Planning or Ratemaking by PUCS or other State Agencies}

We know of no current or prospective plans to incorporate environmental externalities into the utility planning process.

\section{2.) Roles of Utility Regulatory Agencies in State Utility Regulation and Resource Planning}

The Alabama Public Service Commission has sole regulatory responsibility and jurisdiction for utility operations but other state agencies have separate functions in the utility planning process.

\section{3.) Supply/Demand Balance}

Alabama generating capacity is $64 \%$ fossil fuels; $19 \%$ nuclear and $17 \%$ from hydro. The state has enough baseload power, but expects to need additional capacity to meet peak power demands in the next five to ten years. The state's only electric utility annually furnishes the Commission information on peak demand growth and the system's generation expansion plan to include future capacity requirements, purchased power requirements and sales, and sales from QFs. IPPs are not a part of the aforementioned.

\section{4.) Resource Planning and Acquisition}

We have no information on current or prospective plans to develop least cost planning or the role of bidding in meeting new capacity needs.

Respondent: Charles B. Stults

Title: Director, Energy Division

Phone number: $\quad$ 205-242-5868

Address: $\quad$ Alabama Public Service Commission

P.O. Box 991

502 Washington Avenue

Montgomery, AL 36101-0991

(Responses confirmed by mail). 


\section{State Commission Environmental Externality Survey - Alaska}

\section{1.) Definition and Role of Environmental Externalities in Planning or Ratemaking by PUCS or other State Agencies}

We know of no current or prospective plans to incorporate environmental externalities into the utility planning process.

\section{2.) Roles of Utility Regulatory Agencies in State Utility Regulation and Resource Planning}

The Alaska Public Utility Commission reviews the prudency of utility expenditures, determines appropriate rates of return, and approves new power plant construction, revenue allocation and rate design. We have no information on the role and jurisdiction of other state agencies in the utility planning process.

\section{3.) Supply/Demand Balance}

The Anchorage area generates its electricity from gas and the Fairbanks area uses coal and oil. The state has no need for base or peak power in the foreseeable future. We have no other information on energy and peak demand growth (state or utility) or preferred supply strategies (add new capacity, purchases, QFs, IPPs).

\section{4.) Resource Planning and Acquisition}

In April 1987, a least cost planning law was introduced in the legislature, but did not pass. We have no information on the status of any further least cost planning efforts or the role of bidding in meeting new capacity needs.

Respondent: Carolyn Guess

Title: Commissioner

Phone number: $\quad 907-276-6222$

Address: $\quad$ Alaska Public Utilities Commission

420 L. Street, Suite 100

Anchorage, Alaska 99507 


\section{State Commission Environmental Externality Survey - Arizona}

\section{1.) Definition and Role of Environmental Externalities in Planning or Ratemaking by PUCS or other State Agencies}

The Arizona Corporation Conmmission (ACC) considers environmental externalities, such as sulfur oxide and carbon dioxide emissions, in its least cost planning activities. The Commission's rules do not specify a method by which such externalities must be considered.

\section{2.) Roles of Utility Regulatory Agencies in State Utility Regulation and Resource Planning}

The Arizona Corporation Commission reviews the prudence of utility expenditures, determines appropriate rates of return, sets rates, and conducts other regulatory activities. No other agency has a statutory authority to set rates for utilities, but environmental quality is regulated by other agencies.

\section{3.) Supply/Demand Balance}

The predominant fuels for generating electricity are coal and nuclear. The state will not need additional generating capacity for several years. Resource plans will be evaluated in 1990 and supply and demand management programs, including conservation, will be reviewed at that time. The need for additional generating capacity, conservation programs, and new technologies will be assessed as part of the Commission's resource planning activities.

\section{4.) Resource Planning and Acquisition}

A Commission rule adopted in 1989 requires the four major utilities to submit a ten year integrated supply and demand analysis every third year. The utilities are required to update demand- and supply-side data annually. The Commission then reviews the utilities' plans in a hearing where all interested parties have a chance to provide input. The Commission may use its findings from its review of the utilities' resource plans to guide its decisions on putting generating units into rate base, on approving applications for financing, and on other matters involving supply and demand issues. Bidding is not required as a means of meeting new capacity needs, although a utility may propose bidding methods.

Respondent: David Berry

Title: ' Chief, Economics and Research (Utilities Division)

Phone number: 602-542-5517

Address: $\quad$ Arizona Corporation Commission 1200 West Washington

Phoenix, AZ 85007

(Responses confirmed by mail) 


\section{State Commission Environmental Externality Survey - Arkansas}

\section{1.) Definition and Role of Environmental Externalities in Planning or Ratemaking by PUCS or other State Agencies}

The Arkansas Public Service Commission has the authority to require utilities to undertake energy conservation measures and to allow the recovery of resulting costs. It may also require utilities to furnish reports concerning actions taken to encourage customers to conserve energy. Environmental protection, energy efficiency, and alternative renewable and nonrenewable technologies are taken into consideration in siting proceedings, which also require an environmental impact statement to be submitted.

\section{2.) Roles of Utility Regulatory Agencies in State Utility Regulation and Resource Planning}

The Arkansas PSC reviews the prudency of utility expenditures, determines appropriate rates of return, and approves revenue allocation and rate design. Although other state agencies may be parties to proceedings for obtaining a certificate of environmental compatibility and public need, the PSC alone has the authority to certificate new power plant sites of at least fifty megawatts by resolving all matters concerning plant location, financing, construction, and operation. A separate permit for air pollution must be obtained for new power plants from the State Department of Pollution Control and Ecology.

\section{3.) Supply/Demand Balance}

The state generates most of the electricity from coal $(55 \%)$ and nuclear $(25 \%)$, with the remainder from gas/oil (10\%) and hydro (10\%). Although the state has enough excess capacity to meet base and peak demands through the 1990s, the Arkansas PSC recently issued an order urging the state's largest electric utility to focus its efforts on demandside alternatives to delay as long as possible the need for construction of new capacity. Energy and peak demand growth is expected to average $2 \%$ per year through the 1990 s.

\section{4.) Resource Planning and Acquisition}

Arkansas does not yet have a least cost planning process. However, each utility must file annually a forecast of loads and resources covering at least the next two years. The Arkansas PSC has the authority to require longer-range forecasts. 
Respondent: Lou Ann Westerfield

Title: $\quad$ Senior Policy Analyst - Electric

Phone number: 501-682-5771

Address: $\quad$ Arkansas Public Service Commission 1000 Center Building

PO Box C-400

Little Rock, AR 72203

Respondent: Walter Nixon

Title:

Special Counsel

Phone number: $\quad 501-376-4000$

Address: $\quad$ Arkansas Public Service Commission 1000 Center Building

PO Box C-400

Little Rock, AR 72203

(Responses confirmed by mail) 


\section{State Commission Environmental Externality Survey - California}

\section{1.) Definition and Role of Environmental Externalities in Planning or Ratemaking by PUCS or other State Agencies}

Both the California Public Utility Commission (CPUC) and the California Energy Commission (CEC) currently have proceedings in which the treatment and quantification of environmental impacts are being considered. As part of its'long term resource planning function, the California Energy Commission (CEC) issues a biennial Electricity Report. For the 1990 Electricity Report (ER 90), the CEC staff has proposed employing estimates of dollar values for emission reductions. The estimates would reflect the value of cutting emissions beyond that required under emission limits and is motivated in large part by air quality problems in the South Coast Air Quality Management District (SCAQMD). The dollar value placed on emissions would be based on the cost of control in the SCAQMD's Tier 1 efforts and represent average costs for a selected group of controls that offer major emission reductions. Table A-1 presents the CEC staff's values for major air emissions: $\mathrm{NO}_{\mathrm{x}}, \mathrm{SO}_{\mathrm{x}}$, reactive organic gas (ROG) emissions, and particulate matter less than ten microns (PM10). ${ }^{1}$

\section{Table A-1. CEC Staff Estimates of Emission Values.}

\begin{tabular}{|ll|}
\hline Pollutant & $\$ /$ ton \\
\hline $\mathrm{NO}_{\mathrm{x}}$ & 11,600 \\
$\mathrm{SO}_{\mathrm{x}}$ & 11,500 \\
PM10 & 7,800 \\
$\mathrm{ROG}$ & 3,300 \\
\hline
\end{tabular}

For $\mathrm{CO}_{2}$, the CEC Staff proposes that $\$ 7 /$ ton be used to reflect the cost of urban reforestation, which represents the lowest cost for mitigation and would add about 1.5-8 mills/kWh to the cost of a coal-fired plant. ${ }^{2}$ The CEC staff position is being examined and reviewed by utilities and others in hearings and workshops; ultimately the CEC will adopt its recommended approach in the final Electricity Report. If used, these numbers will be converted to a dollar value per $\mathrm{kWh}$ (dependent on fuel type) and will be used by utilities in formulating their long range resource plans.

Simultaneously, the CPUC is considering how to quatify and incorporate environmental impacts into the CPUC's existing Standard Offer \#4 (SO4) pricing methodology and bidding protocol. ${ }^{3}$ The CPUC held workshops on this topic in February-May 1990.

1 California Energy Commission Staff Report. November 21, 1989. "Valuing Emission Reductions for ER90," p. B-5.

2 California Legislature Joint Committee on Energy Regulation and the Environment. April 1990. "Electric Resources and Environmental Impacts: Draft Phase I Report," prepared by C.R. Roach, E.P. Kahn, and D.L. Modisette.

3 California Public Utility Commission, 1989. OII.89-07-004. "Order Instituting Investigation on the Commission's own motion to implement the Biennial Resource Plan update following the CEC's Seventh Electricity Report." 
The most important issues raised by the parties raised were 1) treatment of residual environmental impacts; 2) whether environmental impacts should be accounted for in resource planning or acquisition, or both; 3) pollutant versus technology based adders, and; 4) determination of the net emissions of the QF as compared with the utility's "identified deferrable resource (IDR)."4

\section{2.) Roles of Utility Regulatory Agencies in State Utility Regulation and Resource Planning}

The California Public Utility Commission reviews the prudency of utility expenditures (including DSM), determines appropriate rates of return, and approves revenue allocation and rate design. The CPUC also develops long-term resource plans, including DSM program effects, for purposes of establishing the need for and prices paid to qualifying facilities (long-term standard offers) in its Biennial Resource Plan update proceeding.

The California Energy Commission (CEC) was created in 1974 with broad authority in four principal areas: energy forecasting and planning, power plant siting, energy efficiency and conservation, and development of alternative energy sources. The CEC approves new plant sites over fifty megawatts, issues a biennial state demand and supply forecast, and develops criteria for balancing economic and environmental issues. The CEC also promotes energy conservation by developing building and appliance standards and demonstrating new technologies.

\section{3.) Supply/Demand Balance}

California generates approximately $40 \%$ of its electricity from natural gas, $15 \%$ $20 \%$ from hydro, $10 \%$ from nuclear, with the rest coming from renewables and out-ofstate purchases. The state may need to add generating capacity by the mid to late 1990 s.

\section{4.) Resource Planning and Acquisition}

California does not have a formal least cost planning process. The CEC issues a biennial state energy forecast to determine the need for new capacity and the PUC holds rate cases for each utility eve third year. The legislature has passed building standards (Title 24) and appliance standards (Title 20).

If the state needs capacity, QFs are allowed to bid for the capacity need. Price is the only selection factor and winning bidders are paid the price bid by the lowest bidding loser (i.e., a "second-price" auction). Since the state has excess capacity, this system has

4 California Public Utilities Commission, April 13, 1990, O11.89-04-007. "Workshop Report: Incorporating Environmental Adders into the Biennial Resource Plan Update Proceeding," prepared by C. Murley, T. Thompson, and T. Wilsie. 
never been implemented. In 1988, the California utilities proposed that all IPPs, demand-side management programs, and bulk power producers be allowed to bid in a multi-attribute bidding system in which winners would all be paid at the price of their individual bids. However, the CPUC has deferred the utility proposal for now and is committed to implementing the adopted second price auction system.

In addition, in July 1989, the utilities, the CPUC, the CEC, and various stakeholder groups agreed to work together in order to reinvigorate and increase utility DSM programs as part of a collaborative process. The groups participating in the Collaborative process issued a report in January 1990 in which the utilities agreed to significantly expand their DSM programs and develop shareholder incentive mechanisms for these programs. The utilities filed formal applications in April 1990 requesting approval for the expenditures associated with the expanded DSM programs and the financial incentive mechanism.

Respondent: Don Schultz

Title: $\quad$ Supervisor, Division of Ratepayer Advocates

Phone number: $\quad$ 916-324-5935

Address: $\quad$ California Public Utilities Commission

1107 Ninth St Suite 710

Sacramento, CA 95814

(Responses confirmed by mail) 


\section{State Commission Enyironmental Externality Survey - Colorado}

\section{1.) Definition and Role of Environmental Externalities in Planning or Ratemaking by PUCS or other State Agencies}

Environmental and economic extemalities are included in the QF bidding process. In 1988, the Commission approved biennial QF bidding for up to twcaty percent of each utility's demand forecast The bids will be evaluated by an independent third party. Bidding is dono on a hundred point scale. Zero to twelve points are given for fuel type. The fuel type points include onvironmental and economic extemalities. Renewables are given an acditional five point bonus at the end of the bidding process. ${ }^{5}$ Due to capacity abundance, no $Q F$ power bas actually been sought through the $Q F$ bidding process. No QF bids are expected until the mid-1990s.

Table A-2. Colorado's QF Bidding System.

\begin{tabular}{|l|l|}
\hline Fuel Type & \multicolumn{1}{|c|}{ Credits } \\
\hline Renewables & 12 \\
Coal & 5 \\
Natural Gas & 2 \\
Oil & 1 \\
\hline
\end{tabular}

2.) Roles of Utility Regulatory Agencies in State Utility Regulation and Resource Planxing

The Public Utility Commission reviews the prudency of utlity expenditures, determines appropriate rates of return, and approves new power plant construction, revenue allocation and rate desiga. Other state agencies, such as the Department of Health, participate in plant siting.

\section{3.) Supply/Demand Balance}

Colorado generates over $90 \%$ of its electricity from coal. The state does not expect to need new base or peak capacity before the mid-1990s. The latest PUC forecast indicates electricity sales will grow $2.9 \%$ per year, with the summer peak increasing by $3.0 \%$ through 1996.

5 Public Utilicies Commission of Colorado. June 9, 1989. "Amendment to Public Service Company of Colorado Request for Proposals from Qualifying Facilicies." 


\section{4.) Resource Planning and Acquisition}

- Starting in 1985, the PUC attempted to develop least cost planning rules, but they have been unable to overcome opposition from utilities and the legislature. QF bidding has been approved by the Commission and is described above in the section on externalities.

Respondent: Gary Schmitz

Title: $\quad$ Senior Economist

Phone number: $\quad 303-894-2030$

Address: $\quad$ Colorado Public Utilities Commission 1580 Logan St, OL2

Denvex, CO 80203

(Responses confirmed by mail) 


\section{State Commission Environmental Externality Survey - Connecticut}

\section{1.) Definition and Role of Environmental Externalities in Planning or Ratemaking by PUCS or other State Agencies}

A collaborative process between the utilities and the public parties incorporates economic and some environmental externalities in a qualitative tuanner. A ranking system for bidding (both supply and demand) includes consideration of externalities in the ranking criteria. At this time, it has not been determined how each factor will be weighed. The utilities must submit a plan for Department approval at the time capacity need is determined. State law provides for the authority to grant utilities up to a $5 \%$ bonus rate of return for conservation investments due to the environmental benefits of demand-side resources.

\section{2.) Roles of Utility Regulatory Agencies in State Utility Regulation and Resource Planning}

The Connecticut Department of Public Utility Control (DPUC) reviews the prudency of utility expenditures, determines appropriate rates of return, and approves new power plant construction, revenue allocation and rate design. The State Energy Office, the Office of Consumer counsel, and Department staff participate in regulatory proceedings and the collaborative process for C\&LM program design. The DPUC and Siting Council review demand forecasts and supply and demand plans annually. If new capacity is needed, the bidding process will begin. The DPUC has a role in reviewing and approving projects.

\section{3.) Supply/Demand Balance}

In 1989, Connecticut generated $50 \%$ of its electricity from nuclear, $10 \%$ from coal, $32 \%$ from oil, and $8 \%$ from gas, hydro, wood, and refuse. The state has no need for base or peak power in the next five years.

\section{4.) Resource Planning and Acquisition}

Connecticut's two major electric utilities must file an annual forecast of loads and resources as planned to meet future needs through a least cost planning process. In addition the utilities must submit a biennial avoided cost report. When utilities need capacity, bidding is used to obtain supply- or demand-side resources. The DPUC approves the avoided cost and the weighting criteria. The utilities evaluate and rank projects with final approval required by the DPUC. The combined forecast of load and resources, conservation and supply bidding regulations, and the collaborative C\&LM program design process constitute the state's LCUP process.

Respondent: Christopher S. Wood

Title:

Executive Director

Phone number: $\quad$ 203-827-1553

Address: $\quad$ Connecticut Department of Public Utility Control

One Central Park Plaza

New Britain, Connecticut 06051

(Responses confirmed by mail) 


\section{State Commission Environmental Externality Survey - Delaware}

\section{1.) Definition and Role of Environmental Externalities in Planning or Ratemaking by PUCS or other State Agencies}

Wo know of no current or prospective plans to incorporate environmental externalities into the utility planning process.

\section{2.) Roles of Utility Regulatory Agencies in State Utillty Regulation and Resource Planning}

The Public Service Commission reviews the prudency of utility expenditures, determines appropriate rates of return, and approves new power plant construction, revenue allocation and rate design. The Public Service Commission also approves costs for newly constructed power plants and purchases of energy and capacity as well as reviewing and approving proposals for demand-side management.

\section{3.) Supply/Demand Balance}

Delaware generates approximately $60 \%$ of its electricity from coal. The state will need both base and peak power within the next few years. Recent capacity additions have been gas fired. The next two years capacity additions will be gas and oil fired. Base load additions under consideration include capacity purchases from non-utility generators and new coal fired base load additions.

\section{4.) Resource Planning and Acquisition}

Delaware has no formal least cost planning process. However, in 1987, the only major electric utility, Demarva Power and Light, filed a twenty year load and resource plan called Challenge 2000. The plan includes DSM potertial and load and resource data will be periodically updated. There is a growing interest at the Commission in the area of least cost planning. It is expected that least cost planning will receive greater attention in future proceedings.

The state has no formal bidding procedure, but, in response to rapid growth, Delmarva Power and Light has developed its own bidding procedures and issued a RFP.

Respondent: Richard Latourette

Title: $\quad$ Public Utilities Analyst III

Phone number: $\quad 302-736-4249$

Address: Delaware Public Service Commission

P.O. Box 457

Dover, Delaware 19903-0457

(Responses confirmed by mail) 


\title{
State Commission Environmental Externality Survey - Distrist of Columbia
}

\section{1.) Definition and Role of Environmental Externalities in Planning or Ratemaking by PUCS or other State Agencies}

In January 1990, the Public Service Commission proposed regulations regarding the filing of least cost plans by electric and natural gas companies. ${ }^{6}$ The proposed rules direct the applicant to use both economic and non-economic criteria in demand-side and supply-side roption screening. The proposed rules do not require the consideration of environmencal externalities in the least cost planning integration process. However, the Commission stated in the order:

\begin{abstract}
Although the Commission will not, at this time, adopt a specific method to incorporate environmental externalities in the integration phase of least cost planning, we are in the process of reviowing developments in other jurisdictions such as Wisconsin and New York on this issue. In this regard the Commission may in the future promulgate regulations concerning the manner in which environmental externalities may be the manner in which environmental externalities may be incorporated into the integration phase. (Order No. 9417, p.40)
\end{abstract}

\section{2.) Roles of Utility Regulatory Agencies in State Utility Regulation and Resource Planning}

The Public Service Commission reviews the prudency of utility expenditures, determines appropriate rates of return, and approves new power plant construction, revenue allocation and rate design. Currently, the Commission is considering requiring a Certificate of Need for power generation built outside the District, but designed to serve the loads of DC customers. The DC Energy Office participates as an intervenor in utility proceedings.

\section{3.) Supply/Demand Balance}

Potomac Electric Power (PEPCO) has recently experienced annual growth in peak demand of $4.7 \%$. PEPCO currently forecasts an annual growth rate of $3.5 \%$.

PEPCO is currently seeking permission to construct the following new generation totaling over $1 \mathrm{inO} \mathrm{MW}$ :

*750 MW at Dickerson, MD; two 375-MW integrated combined-cycle coalgasification units.

6 District of Columbia Public Service Commission. January, 1990. "Provisions for Electric Utulity Least-Cost Planning," "Order No. 9417." 
*210 MW at Benning Rd., DC; two 105-MW oil-fired combustion turbines (CT).

*160-200 MW at Chalk Pt., MD; two gas CTs, 80-100 MW each.

PEPCO also anticipates the following additional future construction:

* a 50-MW trash-to-energy facility at Dickerson, MD, built by Montgomery Co., MD.

* an 80-MW gas CT at Chalk Pt. to be financed and owed by Southern MD Electric Cooperative, which currently receives all its requirements from PEPCO.

* two additional gas CTs at Chalk Pt., 80-100 MW each.

PEPCO is negotiating with a few potential QFs in MD and DC. There are limited opportunities for QF or IPP development within PEPCO's service area.

\section{4.) Resource Planning and Regulation}

The Commission requires utilities to file biennial resource plans that compare demand-side and supply-side options on an equal basis. All interested parties can provide input to the resource plans at a public hearing and the Commission has the authority to require utilities to submit an amended plan or to submit its own plan. The first PEPCO least cost plan will be filed in March, 1990. The Commission has no explicit rules on bidding, but bidding could be considered in the context of the review of the PEPCO least cost plan.

Respondent: Rick Morgan

Title: $\quad$ Technical Assistant to Commissioner Long

Phone number: $\quad 202-626-5127$

Address: $\quad$ DC Public Service Commission 450 5th St, 8th Floor

Washington, D.C. 20001 


\section{State Commission Environmental Externality Survey - Florida}

\section{1.) Definition and Role of Environmental Externalities in Planning or Ratemaking by PUCS or other State Age.acies}

We know of no current or prospective plans to incorporate environmental externalities into the utility planning process.

\section{2.) Roles of Utility Regulntory Agencies in State Utility Regulation and Resource Planning}

The Public Service Commission reviews the prudency of utility expenditures, determines appropriate rates of return, and approves new power plant construction, revenue allocation and rate design. We have no information on the role and jurisdiction of other state agencies in the utility planning process.

\section{3.) Supply/Demand Balance}

Florida generates approximately $35 \%$ of its electricity from coal and an additional 45\% split evenly between nuclear, oil, and gas. The state needs both base and peaking capacity in the near future. Summer peak demand grew by 8400 MW between 1979 and 1988 and is anticipated to grow by another $7400 \mathrm{MW}$ between 1989 and 1998 . Two utilities have issued bids for new capacity: Seminole Electric Cooperative and Florida Power and Light Company (FPL). FPL recently sought a need determination to construct approximately $1200 \mathrm{MW}$ of new capacity.

\section{4.) Resource Planning and Acquisition}

Florida has no formal legislation that requires least cost planning, but there is legislation that accomplishes the same result. In 1980, the legislature passed the Florida Energy Efficiency and Conservation Act (366.80-.85, Florida Statutes) which required the Commission to set conservation goals and required utilities to implement demandside management. FEECA established an initial five year goal to reduce electricity use and peak demand by twenty-five percent. The Power Plant Siting Act (403.501-403.519, Florida Statutes) requires the Commission to issue a need determination for any fossil fuel steam facility large than $75 \mathrm{MW}$. As part of this review, the Commission must determine if construction is the least cost alternative available to provide the capacity.

One of the state's major utilities, Florida Power and Light, has recently issued a competitive bidding solicitation for $800 \mathrm{MW}$ to be available as soon as 1994. Other utilities, IPPs, and QFs are all eligible to bid. Price and nonprice factors will be considered.

Respuñudenit: Jänes Deañ

Title: $\quad$ Chief, Bureau of Systems Planning and Conservation

Phone number. $\quad 904-488-8501$ 
Address: $\quad$ Florida Public Service Commission

101State Commission E. Gaines St., Fletcher Bldg.

Tallahasse, Florida 32301 


\section{State Commission Environmental Externality Survey - Georgia}

\section{1.) Definition and Role of Environmental Externalities in Planning or Ratemaking by PUCS or other State Agencies}

We know of no current or prospective plans to incorporate environmental externalities into the utility planning process.

\section{2.) Roles of Utility Regulatory Agencies in State Utility Regulation and Resource Planning}

The Public Service Commission reviews the prudency of utility expenditures and determines appropriate rates of return. The Commission does not approve new power plant construction, but utilities must demonstrate the need for the plant before they are allowed to put it into the ratebase.

\section{3.) Supply/Demand Balance}

Georgia generates approximately $80 \%$ of its electricity from coal and $12 \%$ from nuclear. The state expects to need both base and peak power in the near future. The staff does not produce any studies on the need for new capacity, anticipated large acquisitions, or preferred supply strategies. These are done by the utilities and reviewed by the Commission staff.

\section{4.) Resource Planning and Regulation}

In 1989, the Commission appointed a task force to consider least cost planning. We have no other information on current or prospective plans to develop least cost planning or the role of bidding in meeting new capacity needs.

Respondent: Jim Cole

Title:

Audit Manager

Phone number: $\quad 404-656-6790$

Address: $\quad$ Georgia Public Service Commission

244 Washington St

Atlanta, GA 30334

(Responses confirmed by mail) 


\section{State Commission Environmental Externality Survey - Hawaii}

\section{1.) Definition and Role of Environmental Externalities in Planning or Ratemaking by PUCS or other State Agencies}

Currently, environmental externalities are not incorporated into utility planning, but the Commission is considering doing so in the future.

\section{2.) Roles of Utility Regulatory Agencies in State Utility Regulation and Resource Planning}

The Public Utilities Commission reviews the prudency of utility expenditures, determines appropriate rates of return, and approves new power plant construction, revenue allocation and rate design, and purchased power agreements. The Consumer Advocacy Division (of the Department of Commerce and Consumer Affairs) participates in the formal proceedings related to power plant addition and purchased power agreement before the PUC. If integrated resource planning is adopted, it is foreseeable that these other State agencies may participate more actively in the utility planning process.

\section{3.) Supply/Demand Balance}

Hawaii generates more than ninety percent of its electricity from oil. The state needs both base and peak power and is considering building a deep sea electric cable to bring geothermally produced electricity from Hawaii to Maui, Molokai, and Oahu. Load growth in Hawaii has accelerated in the past few years. To meet this accelerated growth, the utilities have either installed additional oil-fired units (Hawaii, Maui, Kauai) or purchased power from QFs (coal-fired unit and combined-cycle unit on Oahu, Geothermal unit on Hawaii). Currently a DSM pilot study is being conducted on the Island of Kauai under the auspices of the Energy Division, Department of Business and Economic Development.

\section{4.) Resource Planning and Acquisition}

Hawaii has no least cost planning process at present. However, the Commission has instituted a proceeding and an investigation (Docket No. 6617) to require energy utilities in Hawaii to implement reducing the dependency on imported oil is a high priority.

Respondent: $\quad$ Norman Lee

Title: Chief Engineer

Phone number: $\quad 808-548-3990$

Address: $\quad$ Public Utilities Commission

465 South King Street, Room 103

Honolulu, HI 96813

(Responses confirmed by mail) 


\section{State Commission Environmental Externality Survey - Idaho}

\section{1.) Definition and Role of Environmental Externalities in Planning or Ratemaking by PUCS or other State Agencies}

In future rate cases, the Public Utilities Commission may allow higher rates of return for utilities that have aggressive conservation programs, including those that target "lost opportunities". Commission Order No. 22299 (January 1989) 7 states, "we take this opportunity to notify our regulated electric utilities that in future rate cases we will take into account the utility's commitment to energy conservation in determining the allowed rate of return. A utility that aggressively addresses the issues and concerns found in this Order (conservation in particular), all other things being equal, may expect the allowance of higher rates of return than might otherwise be allowed".

\section{2.) Roles of Utility Regulatory Agencies in State Utility Regulation and Resource Planning}

The Commission reviews the prudency of utility expenditures, determines appropriate rates of return, and approves new power plant construction, revenue allocation, and rate design.

\section{3.) Supply/Demand Balance}

Idaho generates approximately half of its electricity from hydro and half from coal. Each utility operating in the state submits a biennial resource management report (RMR) to the Commission forecasting twenty year load growth. The RMR projects energy and peak demand growth and strategies for meeting same.

\section{4.) Resource Planning and Regulation}

Idaho PUC Order No. 22299 (January 1989) states that demand and supply side resources be given equal consideration and establishes criteria for valuing energy conservation. The Order effectively creates least cost planning for the state.

Respondent: Ralph Nelson

Title: Commissioner

Phone number: $\quad$ 208-334-2898

Address: $\quad$ Idaho Public Utilities Commission

State House

Boise, Idaho 83720

(Responses confirmed by mail)

7 Idaho Public Utilites Commission. January 1989. "In the Matuer of the Investigation by the Idaho Public Utilities Commission into Idaho Electricity Conservation Standards and Practices," Order No. 22299. 


\section{State Commission Environmental Externality Survey - Illinois}

1.) Definition and Role of Environmental Externalities in Planning or Ratemaking by PUCS or other State Agencies

Least cost planning by lllinois utilities requires a discussion of environmental externalities, though there is no formal way of accounting for them. We know of no other current or prospective plans to incorporate environmental externalities into the utility planning process.

\section{2.) Roles of Utility Regulatory Agencies in State Utility Regulation and Resource Planning}

The Illinois Commerce Commission (ICC) reviews the prudency of utility expenditures, determines appropriate rates of return, and approves new power plant construction, revenue allocation and rate design. We have no information on the role and jurisdiction of other state agencies in the utility planning process.

\section{3.) Supply/Demand Balance}

Illinois generates approximately $55 \%$ of its electricity from coal and $40 \%$ from nuclear. The state will need additional peaking capacity within a few years, but does not expect to need baseload until the late 1990s. We have no other information on energy and peak demand growth (state or utility) or preferred supply strategies (add new capacity, purchases, QFs, IPPs).

\section{4.) Resource Planning and Acquisition}

In 1985, the Illinois State Assembly passed least cost legislation. In 1987, the Commerce Commission began rule-making proceedings, with input from all interested parties. Utilities will file their first long range resource plans in 1990. We have no information on how often the utilities will have to file resource plans or whether the Commission can require them to resubmit amended plans. We also have no information on the role of bidding in meeting new capacity needs.

Respondent: Tony Visenky

Title: Senior Analyst

Phone number: 217-524-6859

Address: Illinois Commerce Commission

527 East Capitol

Springfield, Illinois 62794-9280

(Responses confirmed by mail) 


\section{State Commission Environmental Externality Survey - Indiana}

1.) Definition and Role of Environmental Externalities in Planning or Ratemaking by PUCS or other State Agencies

We know of no current or prospective plans to incorporate environmental externalities into the utility planning process.

\section{2.) Roles of Utility Regulatory Agencies in State Utility Regulation and Resource Planning}

The Indiana Utility Regulatory Commission (IURC) reviews the prudency of utility expenditures, determines appropriate rates of return, and approves new power plant construction, revenue allocation and rate design.

\section{3.) Supply/Demand Balance}

Indiana generates over $90 \%$ of its 'ectricity from coal. Some utilities need generating capacity, though overall the state has si ficient capacity.

\section{4.) Resource Planning and Acquisition}

An electric utility must obtain a Certificate of Need from the Commission it wants to build new generating capacity. The Certificate of Need law states that proposed new capacity must be compared with a wide range of options, including demand-side management. Recently, the Commission decided that the planning process required by the Certificate of Need law is synonymous with least cost planning. Three of the state's generating utilities have been ordered by the Commission to submit least cost plans prior to the end of 1990 and biennially thereafter. The Commission is in the very early stages of developing guidelines that electric utilities should follow when developing least cost plans.

Currently, there are not plans for the IURC to encourage a bidding process to meet new capacity needs. However, one Indiana utility has started a bidding process to acquire peak capacity and/or demand-side resources to meet future generating needs.

Respondent: Bradley Borum

Title: $\quad$ Assistant Chief Economist - Technical Section

Phone number: $\quad 317-232-2304$ 
Address: Indiana Utility Regulatory Commission 904 State Office Building

Indianapolis, IN 46204

Respondent: Greg Turk

Phone number: $\quad$ 614-486-6711

Address: Indiana Public Service Commission

301 State Office Building

Indianapolis, IN 46204

(Responses confirmed by mail) 


\section{State Commission Environmental Externality Survey - Iowa}

\section{1.) Definition and Role of Environmental Externalities in Planning or Ratemaking by PUCS or other State Agencies}

In 1989, the Iowa Utilities Board hired a consultant to make recommendations on planning, cost recovery, and energy efficiency programs. ${ }^{8}$ After consultation with a large working group including representatives from utilities, business, academia, and low income and environmental groups, the consultant recommended that environmental externalities should initially be accounted for by a credit (e.g. 10\%) to the avoided supply cost used within the societal cost/benefit test. The consultant also recommended that for the long term, utilities should develop and refine specific credits $(\$ / \mathrm{kWh}, \$ / \mathrm{therm}$, etc.) to address externality benefits of demand-side activities.

The Iowa Utilities Board has endorsed the externality recommendations. A working group consisting of utility representatives, Utilities Board staff, and Office of Consumer Advocate staff has been working to develop rule changes to the Iowa Administrative Code to incorporate the externality considerations.

\section{2.) Roles of Utility Regulatory Agencies in State Utility Regulation and Resource Planning}

Through rate cases, the Iowa Utilities Board reviews the prudency of utility expenditures, determines appropriate rates of return, revenue allocation and rate design. Currently, electric utilities must apply to the Board before constructing generating facilities greater than $25 \mathrm{MW}$. The consultant has recommended that the limit be lowered to $20 \mathrm{MW}$. Applications for construction permits are reviewed by other state agencies for compliance with state environmental statutes.

\section{3.) Supply/Demand Balance}

Iowa generates approximately $75 \%$ of its electricity from coal and $25 \%$ from nuclear. The average annual sales growth of the seven investor-owned electric utilities was $2.5 \%$ from 1981 to 1988 . The electric utilities have projected growth in demand of $1.2 \%$ per year through the 1990s. The state has ample baseload capacity, but several utilities are building peaking capacity. The preferred supply strategy for peaking capacity appears to be natural gas fired combustion turbines. The consultant proposed that electric utilities control growth in demand by aggressive programs of demand-side management, which will result in little need for new generating capacity over the next ten years.

\footnotetext{
8 Morgan Systems. October 27, 1989. "Energy Efficiency Options Study Main Report," prepared for The Iowa State Utilities Board, Berkeley, CA.
} 


\section{4.) Resource Planning and Acquisition}

Investor owned electric utilities are required to file annual reports of planning information. If power plant certificates will be needed within five years, the reports must contain detailed information on reserves, load forecasts, and supply and demand options. Investor owned gas utilities must file five year forecasts and procurement plans.

Investor owned electric utilities are required to file a comprehensive energy management plan when applying for rate increases or in order to get a construction permit for a $25 \mathrm{MW}$ or greater capacity power plant.

The consultant made the following recommendations concerning utility resource planning and management.

1.) Refine and improve forecasting methods to support integrated resource planning.

2.) Extend planning horizon to twenty years.

3.) Adopt societal benefit/cost test.

4.) Establish avoided costs.

5.) Establish goals for energy efficiency expenditures of 1.5\%-2.0\% of utility gross operating revenues.

6.) Require aggressive demand-side data collection by utilities.

7.) Refine evaluation and measurement methods.

The working group consisting of utility representatives, Utilities Division staff, and Office of Consumer Advocate staff is developing rule changes to the Iowa Administrative Code to implement these recommendations.

Respondent: Gordon Dunn

Title: $\quad$ Supervisor, Energy Efficiency Section

Phone number: $\quad$ 515-281-7051

Address: $\quad$ Iowa State Utilities Board Lucas Building

Des Moines, IA 50319

(Responses confirmed by mail) 


\section{State Commission Environmental Externality Survey - Kansas}

\section{1.) Definition and Role of Environmental Externalities in Planning or Ratemaking by PUCS or other State Agencies}

The Kansas State Corporation Commission (KSCC) permits the utlities a higher rate of return on projects that use renewable energy, conservation, or higher efficiency than is normally allowed. The increase in allowed rate of return (ROR) ranges from $0.5 \%$ to $2.0 \%$. (The RORs for four major utilities in the state are $10.07 \%$ to $11.99 \%$ ).

\section{2.) Roles of Utility Regulatory Agencies in State Utility Regulation and Resource Planning}

The KSCC reviews the prudency of utility expenditures, determines appropriate rates of return, and approves new power plant construction, revenue allocation and rate design.

\section{3.) Supply/Demand Balance}

Kansas generates $95 \%$ of its electricity from coal and $2 \%$ from nuclear. The state will need peaking power in some regions in the near future.

\section{4.) Resource Planning and Acquisition}

In 1987, the KSCC began requesting that the major electric utlities (KG\&E, KCP\&L, Centel, Empire District Electric, and Midwest Energy) file annual load management reports giving equal status to demand.

Respondent: Shirley Sicilian

Title: $\quad$ Chief, Office of Economic Policy

Phone number: $\quad$ 913-296-2757

Address: $\quad$ Kansas Corporation Commission 4th Floor Docking State Office Bldg. Topeka, KS 66612 
Respondent: Philip Sanchez

Titlo: $\quad$ Enorgy Research Analyst II

Phone number: 913-296-4195

Address: Kansas Corporation Commission

4th Floor Docking State Office Bldg.

Topeka, KS 66612

(Responses confirmed by mail) 


\section{State Commission Environmental Externality Survey • Kentucky}

\section{1.) Definition and Role of Environmental Externalities in Planning or Ratemaking by PUCS or other State Agencles}

We know of no current or prospective plans to incorporate environmental externalithes into the utility planning process.

\section{2.) Roles of Utillty Regulatory Agencies in State Utility Regulation and Resource Planning}

The Public Service Commission reviews the prudency of utility expenditures, determines appropriate rates of return, and approves new power plant construction, revenue allocation and rate design. We have no information on the role and jurisdiction of other state agencies in the utility planning process.

\section{3.) Supply/Demand Balance}

Kentucky generates approximately $96 \%$ of its electricity from coal. The state has adequate base capacity through 1998, but may add peak capacity in the form of oil and gas-fired combustion turbines over the next eight years. The latest utility forecasts indicate that electricity sales will grow an average of $1.6 \%$ per year through 1998, with annual summer and winter peaks increasing an average of $1.8 \%$.

\section{4.) Resource Planning and Acquisition}

The PSC is in the process of developing an integrated resource planning regulation. This regulation would require electric utilities to file biennial demand forecasts and resource assessment and acquisition plans. An implementation date for this regulation is unknown at the present time.

Respondent: Mike Alexander

Title: $\quad$ Economist

Phone number: $\quad$ 502-564-2982

Address: Kentucky Public Service Commission

Research Division

P.O. Box 615

Frankfort, KY 40602

(Responses confirmed by mail) 


\section{State Commission Environmental Externality Survey - Louisiana}

\section{1.) Definition and Role of Environmental Externalities in Planning or Ratemaking by PUCS or other State Agencies}

We know of no current or prospective plans to incorporate environmental externalitios into the utility planning process.

\section{2.) Roles of Utility Regulatory Agencies in State Utility Regulation and Resource Planning}

The Public Service Commission reviews the prudency of utility expenditures, determines appropriate rates of return, and approves new power plant construction, revenue allocation and rate design. We have no information on the role and jurisdiction of other state agencies in the utility planning process.

\section{3.) Supply/Demand Balance}

Louisiana generates approximately $40 \%$ of its electricity from gas, $30 \%$ from coal, and $30 \%$ from nuclear. The state has a large excess of capacity and does not expect to need base or peak capacity before the year 2000 . We have no other information on energy and peak demand growth (state or utility), anticipated large acquisitions, or preferred supply strategies (add new capacity, purchases, QFs, IPPs).

\section{4.) Resource Planning and Acquisition}

We have no information on current or prospective plans to develop least cost p'anning or the role of bidding in meeting new capacity needs.

Respondent: Robert Crowe

Title: Utility Specialist

Phone number: $\quad$ 504-342-1413

Address: $\quad$ Louisiana Public Service Commission

P.O. Box 91154

Baton Rouge, LA 70821

(Responses confirmed by mail) 


\section{State Commission Environmental Externality Survey - Maine}

\section{1.) Definition and Role of Environmental Externalities in Planning or Ratemaking by PUCS or other State Agencies}

In 1988, legislation was proposed (but did not pass) to weight DSM cptions by 120 percent to account for their environmental benefits. In April 1990, the Niwine legislature passed a statute that requires the PUC to conduct an analysis of the environmental impacts of alternate energy resource plans in utility proceedings. ${ }^{9}$ While no formal proceeding has been opened, the Commission staff is reviewing this policy area.

\section{2.) Roles of Utility Regulatory Agencies in State Utility Regulation and Resource Planning}

The Public Utilities Commission reviews the prudency of utility expenditures, determines appropriate rates of return, approves new power plant construction, revenue allocation and rate design, reviews each utility's annual filing of 30-year energy resource plan and avoided cost calculation, and monitors cost-effectiveness of energy management and power purchases. The Office of Public Advocate typically takes part in these proceedings. The State Planning Office maintains informal contact with the regulatory process.

\section{3.) Supply/Demand Balance}

Maine generates approximately $20 \%-25 \%$ of its electricity from nuclear and $25 \%$ from hydro. Another $35 \%$ is accounted for by purchases from Canada and non-utility generators with the balance being produced from oil. The state does not plan to add much base or peak capacity, but plans to meet the needs through purchases and DSM. The utilities' long-term load forecasts project growth in energy sales of about $2.5 \%$ per year from 1988 to 2003, with no new utility DSM. With QF buy/sell contracts, netted out, growth is $1.7 \%$ per year, with peak load growing by $776 \mathrm{MW}$ or $2.2 \%$ per year. Substantial portions of these added loads will be met with DSM.

\section{4.) Resource Planning and Acquisition}

The PUC has the authority to order utilities to invest in conservation. Utilities must submit quarterly and annual reports to recover their conservation investments. The PUC has adopted three tests for evaluating the benefits of conservation: the All Ratepayers Test, the Rate Impact Test, and the Societal Test. The PUC reviews conservation performance during general rate cases.

Maine has also implemented competitive bidding. The Commission encourages a hands off bidding process. Utilities wishing to construct, purchase or contract for generation or transmission facilities may be required to show that they have solicited competing hids. Utiiities annually calculate. with Commission review, the 30 -year avoided costs associated with two successive load decrements of $50 \mathrm{MW}$ each " or $10 \%$ of peak

9 Chapter 110, PNS "Act to Require PUC to Conduct Analysis of a Comparative Environmental and Economic Impacts of Alternate Energy Resource Plans in Utility Proceedirgs," April 1990. 
demand, whichever is less. The resulting cost streams are, in effect, the base price against which competing bids will be evaluated. The energy resource plan used in the calculation of avoided costs must reflect a joint optimization of demand- and supply-side resources.

Respondent: $\quad$ Richard Parker

Title: $\quad$ Senior Utility Planner

Phone number: $\quad$ 207-289-3831

Address: $\quad$ Public Utilities Commission

242 State St.

Augusta, ME 04333

(Responses confirmed by mail) 


\section{State Commission Environmental Externality Survey - Maryland}

\section{1.) Definition and Role of Environmental Externalities in Planning or Ratemaking by PUCS or other State Agencies}

The utilities, the Public Service Commission of Maryland, the Office of Natural Resources, and the cogeneration industry are engaged in a collaborative process to decide how to weight environmental costs in a proposed bidding process. The PUC is also preparing a separate white paper on how to quantify externalities, particularly environmental ones. Up until now, the costs have been assumed to be zero since these factors were not weighted.

\section{2.) Roles of Utility Regulatory Agencies in State Utility Regulation and Resource Planning}

The Public Service Commission reviews the prudency of utility expenditures, determines appropriate rates of return, and approves new power plant construction, revenue allocation and rate design. The Departments of Natural Resources, Environment, Transportation, Economic and Employment Development, Agriculture, and State Planning participate in certification of new power plant construction.

\section{3.) Supply/Demand Balance}

Maryland generates more than $50 \%$ of its electricity from coal, with the balance coming from nuclear, oil, and gas. The state needs additional base and peaking capacity. As of 1989, the utilities in the state project peak demand will grow 5500 MW by 2003. To respond to this growth, the utilities are planning to build or purchase $4400 \mathrm{MW}$ of generating capacity and implement measures to reduce peak demand by approximately $1350 \mathrm{MW}$.

\section{4.) Resource Planning and Acquisition}

Since 1976, utilities have been required to file an annual load forecast and long range plan which includes "adequate provisions to promote energy conservation". These forecasts are reviewed and evaluated by the Commission. If deemed appropriate, the Commission shall require revisions to these plans. Utilities must also file a permit for new power plant construction two years before starting construction and must justify the construction as the least cost option. One utility in Maryland, Delmarva Power and Light, has developed a proposal for competitive bidding. Bidding is also under consideration by the other large utilities in the state.

Respondent: Mary Beth Tighe

Title:

Assistant Director for Least-Cost Planning

Răie Reseâuch ẩ Economics Division

Phone number: $\quad 301-333-6024$ 
Address: $\quad$ Public Service Commission of Maryland American Building

231State Commission East Baltimore Street

Baltimore, MD 21202-3486

(Responses confirmed by mail) 


\section{State Commission Environmental Externality Survey - Massachusetts}

\section{1.) Definition and Role of Environmental Externalities in Planning or Ratemaking by PUCS or other State Agencies}

A year ago, the Department of Public Utilities announced a policy of requiring the consideration of environmental externalities explicitly in utilities' analyses and decisions regarding the development or procurement of demand and supply resources. In response, the utilities formed a collaborative working group with other interested parties to explore approaches to quantifying environmental costs. In December 1989, in a rule-making on an integrated resource management process for electric companies, the PUC proposed alternative approaches for incorporating environmental externalities. The PUC intends to adopt a scheme that values externalities similarly across electric companies, as part of least cost planning regulations to be put in place in 1990.

\section{2.) Roles of Utility Regulatory Agencies in State Utility Regulation and Resource Planning}

The Department of Public Utilities reviews the prudency of utility investments and expenditures on generation and demand-side programs, determines appropriate rates of return, establishes rate design, and approves cost recovery for new power plant construction and generation and demand-side programs. Utilities file an annual forecast and supply plan with the Energy Facilities Siting Council (EFSC). These two agencies have recently developed a coordinated integrated resource management process that has just been set forth in proposed regulations. The process would involve the two agencies in a process governing the electric companies' planning for and procurement of supply and demand resources. Additionally, the legislature passed an acid rain bill to cap sulfur dioxide emissions from powerplants.

\section{3.) Supply/Demand Balance}

Massachusetts generates approximately $45 \%$ of its electricity from oil, $30 \%$ from nuclear, $10 \%$ from coal, and $8 \%$ from natural gas. The state needs additional base and peak capacity. We have no other information on energy and peak demand growth (state or utility), anticipated large acquisitions, or preferred supply strategies (add new capacity, purchases, QFs, IPPs). 


\section{4.) Resource Planning and Acquisition}

At present, utilities are required to file an annual forecast and supply plan with the EFSC. Each utility conducts annual bidding, even if it has excess capacity. Bids are solicited from QFs. The minimum bid that a utility must solicit is the incremental capacity for a twenty year load forecast or $5 \%$ of the previous year's peak demand, whichever is larger. Bids are evaluated based on capacity, endurance, security, price, and operation indices. The utility then selects the highest ranked bids.

If the proposed integrated resource management regulations are adopted in a fashion similar to the proposal, electric companies would be required to develop a resource plan in response to forecasted need for new resources. The utilities would be required to bid fixed price terms for its demand and supply proposals. Other demand-side and generation providers would make proposals in competition. All offerings (utility and nonutility) would be judged by criteria pre-approved by the PUC. The evaluation criteria would include price and non-price components, including environmental externalities.

Respondent: Susan Tierney

Title: Commissioner

Phone number: $\quad 617-727-3520$

Address: $\quad$ Massachusetts Department of Public Utilities 100 Cambridge $\mathrm{St}$

Boston, MA 02202

(Responses confirmed by mail) 


\section{State Commission Environmental Externality Survey - Michigan}

\section{1.) Definition and Role of Environmental Externalities in Planning or Ratemaking by PUCS or other State Agencies}

The Public Service Commission is developing methods for including and quantifying environmental externalities in the utilities' integrated resource plans. These criteria are expected to be used in review of the major electric utilities' integrated resource plans that will be submitted in December, 1991 and June, 1992. The December, 1989 and June 1990 plans should consider externalities in an intensive manner.

\section{2.) Roles of Utility Regulatory Agencies in State Utility Regulation and Resource Planning}

The PSC reviews the prudency of utility expenditures, determines appropriate rates of return, revenue allocation, and rate design, but does not have the authority to approve new power plant construction. We have no information on the role and jurisdiction of other state agencies in the utility planning process.

\section{3.) Supply/Demand Balance}

Michigan generates $80 \%$ of its electricity from coal and $17.5 \%$ from nuclear. The state has sufficient peaking capacity, but expects to need more baseload capacity in the mid-1990s. Energy and peak demand growth (state or utility), anticipated large acquisitions, or preferred supply strategies (add new capacity, purchases, QFs, IPPs) are reviewed in the Michigan Energy Options Study (MEOS).

\section{4.) Resource Planning and Acquisition}

Michigan's two major utilities, Detroit Edison and Consumer Power Company, will be filing the state's first least cost utility plans in December, 1989 and August, 1990. The Commission is currently trying to establish planning review for all other electric and gas utilities.

Respondent: Ronald Callen

Title: Technical Assistant to the Director of Planning

Phone number: $\quad$ 517-334-6431

Address: $\quad$ Michigan Public Service Commission

6545 Mercantile, PO Box 30221

Lansing, Michigan 48909

(Responses confirmed by mail). 


\section{State Commission Environmental Externality Survey - Minnesota}

\section{1.) Definition and Role of Environmental Externalities in Planning or Ratemaking by PUCS or other State Agencies}

For over ten years, the state of Minnesota has incorporated environmental considerations into its Certificate of Need process. Environmental externalities such as acid rain and global warming have been considered in need cases. In December 1989, the Public Utilities Commission proposed a resource planning rule that would incorporate environmental considerations. Additionally, in order to reduce the damage from acid rain, the legislature passed a bill in 1986 that caps sulfur dioxide emissions from the state's two main power plants.

\section{2.) Roles of Utility Regulatory Agencies in State Utility Regulation and Resource Planning}

The Public Utilities Commission reviews the prudency of utility expenditures, determines appropriate rates of return, and approves new power plant construction, revenue allocation and rate design. The Department of Public Service and the Environmental Quality Board review the Advance Forecast Reports submitted by the utilities. The Department of Public Service and the Office of the Attorney General are among the state agencies that routinely intervene in Commission dockets. The Environmental Quality Board sites power plants and routes transmission lines. The Pollution Control Agency and the Department of Natural Resources issue permits for new facilities. All of the above agencies probably will participate in the proposed resource planning process. We have no information on the role and jurisdiction of other state agencies in the utility planning process.

\section{3.) Supply/Demand Balance}

Minnesota generates approximately $50 \%$ of its electricity from coal, $25 \%$ from nuclear, and purchases another $20 \%$. The state does not expect to add peak or baseload capacity until the mid 1990s. The lastest (combined) utility forecast (July 1989) indicates annual sales growth to be about $1.7 \%$ through 2003 . Peak demand growth is expected to average about $1.6 \%$ in the summer and $1.4 \%$ in the winter through 2003. Utilities appear to be building new facilities as a last resort. The state's largest utility has expressed a strong interest in life extensions, purchased power, and demand-side management. Large utilities are required by statute to make significant investments in conservation improvement programs. There has been only modest $\mathrm{QF}$ and IPP development in Minnesota. 


\section{4.) Resource Planning and Acquisition}

A least cost planning bill was introduced into the legislature in 1987, but did not pass. The Commission currently is proposing resource planning rules under existing statutory authority. The rule would permit but not mandate a competitive bidding process. The Commission's decision will consist of findings and conclusions that will be used in subsequent regulatory processes. Resource planning filings will be submitted every other year. As indicated earlier, all large power plants and transmission lines proposed for construction in Minnesota must be certified by the Commission as to need prior to construction. All resource options, including demand reduction, are considered in that process.

In 1989, the Legislature shifted administrative authority over conservation improvement programs to the Department of Public Service. Each decision is subject to possible appeal to the Commission. Utilities must file a Conservation Improvement Plan with the PUC. The PUC can order utilities to invest in conservation, rather than new generating capacity, if they think that it is the least expensive option. We have no other information on current or prospective plans to develop least cost planning or the role of bidding in meeting new capacity needs.

Respondent: Susan Mackenzie

Title:

Rates Analyst

Phone number: $\quad 612-297-4562$

Address: $\quad$ Minnesota Public Utilities Commission

American Center Building

Kellogg and Robert Sts

Saint Paul, MN 55101

(Responses confirmed by mail) 


\section{State Commission Environmental Externality Survey - Mississippi}

1.) Definition and Role of Environmental Externalities in Planning or Ratemaking by PUCS or other State Agencies

There are no current plans to incorporate environmental externalities into the utility planning process.

2.) Roles of Utility Regulatory Agencies in State Utility Regulation and Resource Planning

The Public Service Commission reviews the prudency of utility expenditures, determines appropriate rates of return, and approves new power plant construction, revenue allocation and rate design. No other state agencies have a roll or jurisdiction in the utility planning process.

\section{3.) Supply/Demand Balance}

Mississippi generates most of its electricity from a mix of natural gas, coal, and some fuel oil. Mississippi also has a 33\% allocation from Grand Gulf Nuclear Facility located in Mississippi but owned by System Energy Resources. The state has large excesses of capacity and does not expect to need additional baseload or peak capacity within the next several years. No other state agencies have a role or jurisdiction in the utility planning process except the State Department of Energy which has limited areas of responsibility.

\section{4.) Resource Planning and Acquisition}

There are no current plans to develop least cost planning or the role of bidding in meeting new capacity needs.

Respondent: $\quad$ C. Keith Howle

Title:

Director of Administrative Service

Phone number: 601-961-5476

Address: $\quad$ Mississippi Public Service Commission

P.O. Box 1174

Jackson, MS 39215-1174

(Responses confirmed by mail) 


\section{State Commission Environmental Externality Survey - Missouri}

\section{1.) Definition and Role of Environmental Externalities in Planning or Ratemaking by PUCS or other State Agencies}

The Missouri Public Service Commission has recently begun a comprehensive roview of its oversight of the strategic resource planning activities of electric utilities under its jurisdiction. The first step in this process was to establish the Electric Strategic Resource Planning Project team whose mission is to gather information, identify policy options, and make recommendations to the Commission. Although the mandate of the project team is broader than just environmental issues, the impact of potential environmental constraints is certainly a major consideration in developing Commission policy on resource planning oversight.

\section{2.) Roles of Utility Regulatory Agencies in State Utility Regulation and Resource Planning}

In the context of "routine" rate cases, the Public Service Commission Staff submits testimony on the prudency of utility expenditures, appropriate rate of return, class cost allocations, and rate design. The Office of Public Counsel (entirely separate from PSC staff) also enters testimony on these issues. Although the State of Missouri sometimes intervenes in rate cases as a utility consumer, no other state agencies are typically involved in most rate case work.

Commission authority over siting and certification of new facilities is rather limited. The only time a utility is actually required to obtain advance certification for a new facility is in instances where the facility is to be located outside the utility's certificated service territory. Both of the major nuclear plant cases to come before the Commission (Union Electric Company Callaway Plant and Kansas City Power \& Light Company Wolf Creek Plant) were located outside the company's service territory and thus did require certification hearings.

Although the State Department of Natural Resources has the authority to regulate air quality, water quality, and solid waste disposal, these requirements are not explicitly integrated into the resource planning process and the DNR does not have any direct authority over utility resource planning.

\section{3.) Supply/Demand Balance}

The Midwestern region still has ample baseload capacity but current plans call for some additions of peaking capacity by the mid-nineties. Since Missouri generates over $75 \%$ of its electricity from coal, and since some of these plants are relatively dirty, the potential impact of acid rain legislation is large. To the extent that new emission constraints affect net plant capacities or availability rates, they will hasten the need for new capacity. 


\section{4.) Resource Planning and Acquisition}

Least cost planning bills were introduced into the legislature in 1987, 1988 but did not pass. A major reason for this is that they included a provision giving the Commission authority to cancel plants. This provision was championed by the Office of Public Counsel but the Commission was reluctant to support it. Naturally, the utilities vehemently opposed it. Currently, the only resource plan filing requirements' in effect have been ordered on a case-by-caso basis. PURPA standards have been formally adopted for each utility that has filed a general rate case since 1979, but one company has not filed a case since then and so is not yet technically subject to the PURPA standards. Commission orders in this area so far have been very general. In two cases, the companies have been required to file annual reports that describe their "conservation and load management" activities, but no specific goals, standards, or methods have been adopted.

As noted in item 1 above, a Strategic Planning Project Team was established last summer (1989) to begin a comprehensive review of Commission policy in this area. The mission of this team is fourfold: 1) Research and document the legal and legislative basis for Commission authority and jurisdiction. 2) Document the current state of the art and practice of strategic resource planning at each jurisdictional electric company. 3) Document the statutory and legal basis, as well as the procedural mechanisms used by selected other state regulatory agencies to carry out their oversight of the resource planning process. 4) Lay out a menu of policy options, analyze the pros and cons of each, and make recommendations to the Commission about how to proceed.

Current schedules call tasks 1) through 3) to be completed by late winter (Feb-Mar), with the final report and recommendations due by early next summer (June-July). However, an unusually heavy baseload over the next several months delay this schedule. Currently, the Commission staff reviews long-range resource plans, as well as conservation and load management reports, either within the context of rate cases or on an informal basis. However, the Commission has recently formed a staff project team to review the strategic resource planning prosess of the investor owned electric utilities, and anticipates opening a generic resource planning docket in the near future and reviewing resource plans on a more regular process in the near future.

Respondent: Martin Turner

Title: $\quad$ Manager, Research \& Planning

Phone number: $314-751-7523$

Address: $\quad$ Missouri Public Service Commission

P.O. Box 360

Jefferson City, Missouri 65102

(Responses confirmed by mail) 


\section{State Commission Environmental Externality Survey - Montana}

1.) Definition and Role of Environmental Externalities in Planning or Ratemaking by PUCS or other State Agencies

2.) Roles of Utility Regulatory Agencies in State Utillty Regulation and Resource Planning

3.) Supply/Demand Balance

4.) Resource Planning and Acquisition

Respondent: We received no response from the Montana PSC.

Title:

Phone number:

Address: 


\section{State Commission Environmental Externality Survey - Nevada}

\section{1.) Definition and Role of Environmental Externalities in Planning or Ratemaking by PUCS or other State Agencies}

Environmental and economic externalities are considered in a qualitative fashion by the Commission. "When new capacity is needed, the cornmission shall determine whether the (utility's) plan adequately demonstrates the economic, environmental, and other benefits to this state and to the customers of the utility associated with conservation, load management, improvements in efficiency, renewable energy, and hydrogeneration." 10

\section{2.) Roles of Utility Regulatory Agencies in State Utility Regulation and Resource Planning}

The Public Service Commission reviews the prudency of utility expenditures, determines appropriate rates of return, and approves new power plant construction, revenue allocation and rate design. We have no information on the role and jurisdiction of other state agencies in the utility planning process.

\section{3.) Supply/Demand Balance}

Nevada generates $60 \%$ - $65 \%$ of its electricity from coal and about $15 \%$ from gas, with the balance coming from imports and oil. The state needs both baseload and peak capacity. With regard to Nevada Power Company (southern Nevada), the system peak load in summer will increase at an average annual growth rate of approximately $3.2 \%$, including demand-side program effects. For Sierra Pacific Power Company (northern Nevada), system sales are expected to increase $4.5 \%$ per year from 1990 to 1994 and $1.6 \%$ per year from 1995 to 2008 . Resource requirements will be met with demand-side programs, new utlity capacity, interruptibility purchases, qualifying facilities, and possibly independent power producers (IPPs).

\section{4.) Resource Planning and Acquisition}

Comprehensive least cost legislation passed in 1983. Utilities must file long range plans every three years. The hearing on each utility plan is open to all interested parties and the PUC can order the utility to resubmit an amended plan.

The Commission has not issued any bidding procedures, but Sierra Pacific Power Company has issued a RFP for QF capacity. No explicit evaluation criteria or avoided cost is included. We do not know whether the Commission will overrule this bidding procedure.

Respondent: $\quad$ C. Kirby Lampley

Title: Deputy Commissioner

Phone number: $\quad$ 702-687-6080

10 Nevada Senate Bill No. 497, July 1989. 
Address: $\quad$ Public Service Commission of Nevada

727 Fairview Dr.

Carson City, NV 89710

(Responses confirmed by mail) 


\title{
State Commission Environmental Externality Survey - New Hampshire
}

\author{
1.) Definition and Role of Environmental Externalities in Planning or Ratemaking \\ by PUCS or other State Agencies \\ While there is proposed legislation that states the Commission "may consider" \\ environmental externalities in reviewing least cost plans, this has not been put into prac- \\ tice.
}

2.) Roles of Utility Regulatory Agencies in State Utility Regulation and Resource Planning

The Public Utilities Commission reviews the prudency of utility expenditures, determines appropriate rates of return, revenue allocation and rate design and reviews and approves or disapproves required utility least cost planning filings. The Siting Board approves new power plant construction.

\section{3.) Supply/Demand Balance}

New Hampshire generates approximately $30 \%$ of its electricity from oil, $30 \%$ from coal, $10 \%$ from QFs, and gets the remainder from out-of-state purchases. With Seabrook in operation, about $30 \%$ of generation will be nuclear. The state will need peaking capacity in the near future if Seabrook is not on line, but does not expect to need baseload capacity for about ten years. The utilities' least cost planning filings in May 1989 provide information on future utility acquisitions, energy and peak demand growth, and utility resource planning strategies.

\section{4.) Resource Planning and Acquisition}

Since 1989, the Commission has required that utilities file biennial least cost resource plans with a fifteen year load forecast. The resource plan must integrate demand-side and supply-side options and include a two-year implementation plan. The Commission has the authority to require utilities to resubmit amended plans. Individual negotiations with qualifying facilities and independent power producers take place within and outside individual utility bidding programs. The PUC has no preference for bidding. In reviewing utility least cost plans, the emphasis has been on ensuring that utilities use consistent criteria for evaluating demand- and supply-side options and that they select options from a broad and comprehensive set of possibilities. The Commission's least cost planning regulations require utilities to make biennial filings demonstrating that they have have evaluated both demand- and supply-side resources consistently.

Respondent: Janet Gail Besser

Title:

Utility Analyst for Energy Planning

Phone number: $\quad$ 603-271-2431

Address: $\quad$ Public Utilities Commission

8 Old Suncook Rd

Concord, NH 03301

(Responses confirmed by mail) 


\section{State Commission Environmental Externality Survey - New Jersey}

\section{1.) Definition and Role of Environmental Externalities in Planning or Ratemaking by PUCS or other State Agencies}

When utilities need capacity, they use annual bidding to acquire capacity from QFs and IPPs. Weighting factors for the initial bidding program were arrived at as part of a stipulation of agreement between utilities, QF representatives, and Board of Public Utilities (BPU) staff. There are three categories in the bidding process: economic issues (maximurn of 55\%), non-economic issues (minimum of 20\%), and project viability (minimum of 25\%). Non-economic issues include environmental issues and fuel efficiency. In a recent bid, environmental factors and energy efficiency were each weighted at one percent of the total bidding points by Public Service Electric \& Gas Company (PSE\&G). The RFP released by Rockland Electric Company (RECO) in August 1989 provided a weighting of up to $15 \%$ for meeting special environmental criteria. Jersey Central Power \& Light Company's (JCP\&L) RFP released in June 1989 contained a weighting of up to $2 \%$ for reduced $\mathrm{NO}_{x}$ emissions and up to $4 \%$ for higher levels of fuel efficiency.

During the summer of 1989, JCP\&L went out to bid for 270 MW, PSE\&G went out to bid for $200 \mathrm{MW}$, and RECO solicited bids for 100 to $150 \mathrm{MW}$. The preliminary award groups consisted of $25.5 \mathrm{MW}$ of DSM projects for JCP\&L, $47 \mathrm{MW}$ of DSM for PSE\&G, and 6.4 MW of DSM for RECO. Contracts are currently being negotiated.

The next round of utility RFPs is scheduled to be submitted for review by the BPU this summer. It is anticipated that the weightings of environmental factors will again be an issue in the review.

New Jersey also has a Certificate of Need (CON) process for all utility constructed plants over $100 \mathrm{MW}$, or $25 \%$ capacity additions to existing utilities, whichever is smaller. Part of the evaluation required within the CON is an assessment of the environmental effects of the proposed facility. No specific criteria or weightings are mandated in the procedure.

\section{2.) Roles of Utility Regulatory Agencies in State Utility Regulation and Resource Planning}

The Board of Public Utilities reviews the prudency of utility expenditures (including power purchase contracts), determines appropriate rates of return, and revenue allocation and rate design. The Department of Energy Planning and Conservation (DEPC), which was previously responsible for some of these activities, was merged with the BPU in August, 1989. 


\section{3.) Supply/Demand Balance}

New Jersey generates approximately $25 \%$ of its electricity from coal, $20 \%-30 \%$ from nuclear, $10 \%-20 \%$ from oil and gas and non-utility generators, a large portion of which is coal-fired. Approximately $2000 \mathrm{MW}$ of new non-utility baseload are either under construction or in the planning stages with approved purchase power contracts. The state also needs additional peak capacity, which it plans to meet from non-utility sources. One $75 \mathrm{MW}$ combustion turbine is under construction and the remainder of the peak capacity is expected to be met with either non-utility sources or demand-side management. While the bulk of the incremental supply needs in the $90 \mathrm{~s}$ is expected to be met by QF and IPP development, the utilities have entered into several short term purchases from neighboring utilities to bridge the gap until projected QFs come on line. The Board is considering incentive ratemaking mechanisms to foster expanded development of conservation projects, which will hopefully mitigate the need for new generation.

\section{4.) Resource Planning and Acquisition}

Utilities are required to file annual long range resource plans, including non-utility supply- and demand-side project bidding programs. The Board can accept, modify, or reject the plans. However, the utility can build a new power plant without putting it in the resource plan, but the power plant must still meet a least cost test in order to be included in the rate base. Utilities are also required to file biennial conservation plans with the BPU, which can require the utility to resubmit an amended plan. Modifications to these plans can be proposed at any time, subject to BPU review. Bidding procedures are discussed in the section above on externalities.

\section{Respondent: $\quad$ Scott Weiner}

Title: $\quad$ President, Board of Public Utilities

Phone number: 201-648-2013

Address: $\quad$ Board of Public Utilities

Two Gateway Center

Newark, NJ 07102

Respondent: Robert Chilton

Title: $\quad$ Chief, Bureau of Rates \& Tariffs Electric Division

Phone number: 201-648-3621

Address: $\quad$ Board of Public Utilities

Two Gateway Center

Newark, NI 07102

(Responses confirmed by mail) 


\section{State Commission Environmental Externality Survey - New Mexico}

\section{1.) Definition and Role of Environmental Externalities in Planning or Ratemaking by PUCS or other State Agencies}

We know of no current or prospective plans to incorporate environmental externalities into the utility planning process.

\section{2.) Roles of Utility Regulatory Agencies in State Utility Regulation and Resource Planning}

The Public Service Commission reviews the prudency of utility expenditures, determines appropriate rates of return, and approves new power plant construction, revenue allocation and rate design. We have no information on the role and jurisdiction of other state agencies in the utility planning process.

\section{3.) Supply/Demand Balance}

New Mexico generates approximately $90 \%$ of its electricity from coal and $10 \%$ from natural gas. The state has large excesses of baseload and peak capacity and does not expect to add resources in the 1990s. We have no other information on energy and peak demand growth (state or utility) or preferred supply strategies (add new capacity, purchases, QFs, IPPs).

\section{4.) Resource Planning and Acquisition}

The Commission must approve construction permits, but does not analyze proposed construction on a least cost basis. We have no information on current or prospective plans to develop least cost planning or the role of bidding in meeting new capacity needs.

Respondent: Buddy McDowell

Title: Utility Compliance Specialist

Phone number: $\quad 505-827-6940$

Address: $\quad$ Public Service Commission

Post Office Box 2205

Santa Fe, NM 87504-2205 


\section{State Commission Environmental Externality Survey - New York}

\section{1.) Definition and Role of Environmental Externalities in Planning or Ratemaking by PUCS or other State Agencies}

The New York Public Service Commission (NYPSC) has been overseeing the development of bidding programs to acquire new resources by the state's seven investor-owned utilities. Environmental impacts are explicitly included among the factors considered in selected winning bids. The NYPSC's Opinions that established guidelines for utility bidding programs articulated two key principles relating to environmental factors: 1) all permittable projects are not environmentally equal and thus inferior projects should be penalized accordingly, and; 2) the weights for environmental factors relative to each other and relative to other non-environmental factors (e.g., price) should be based on the costs of mitigating the environmental impacts. Based on a NYPSC staff analysis that assesses the environmental impact, a credit in the bidding evaluation process of up to 1.4 cents per $\mathrm{kWh}$ (approximately twenty-four percent of the utility's avoided cost) is given for resources with lower environmental impacts than coal. ${ }^{11}$ The credits assigned to air emissions are the costs of offsetting or preventing those emissions at other existing facilities. For carbon dioxide, the credit is based on 20 percent of cost of reforestation to sequester the emissions. Credits for water and land use impacts are based on studies published by Bonneville Power Administration.

Table A-3. NYPSC externality cost estimates used in bidding systems.

\begin{tabular}{|ll|}
\hline Externality & $\begin{array}{c}\text { Mitigation Cost } \\
(\neq / \mathrm{kWh})\end{array}$ \\
\hline Air Emissions & \\
Sulfur Oxides & 0.250 \\
Nitrogen Oxides & 0.550 \\
Carbon Dioxides & 0.10 \\
Particulates & 0.005 \\
Water Impacts & 0.10 \\
Land Use & 0.40 \\
\hline \hline Total & $\mathbf{1 . 4 0 5}$ \\
\hline
\end{tabular}

2.) Roles of Utility Regulatory Agencies in State Utility Regulation and Resource Planning

11 New York Public Service Commission (NYPSC). April 12, 1989. "Opinion and Order Establishing Guidelines for Bidding Program," Case 88-E-241, Proceeding on Motion of the Commission (established in Opinion No. 8o-15) as to the guidelines for hidding to meet future electric capacity needs of Orange and Rockland Utilities, Inc., 89-7. 
The Public Service Commission reviews the prudency of utility expenditures, determines appropriate rates of return, and approves new power plant construction, revenue allocation and rate design. The State Energy Office, the Department of Environmental Conservation, and the Department of Public Service prepared a State Energy Plan in 1989 which guides the state utility planning through the year 2010 and establishes goals for DSM programs.

\section{3.) Supply/Demand Balance}

New York needs both baseload and peak capacity in the near future. We do not know what the predominant electricity-producing fuels are and we have no other information on energy and peak demand growth (state or utility), anticipated large acquisitions, or preferred supply strategies (add new capacity, purchases, QFs, IPPs).

\section{4.) Resource Planning and Acquisition}

A Commission ruling ${ }^{12}$ permits the NYPSC to require utilities to invest in load management and conservation. In December 1986, the Commission staff released guidelines for utility demand-side management programs, recommending that utilities invest $0.25 \%$ of their revenues in conservation.

If utilities need capacity, they solicit bids from QFs and IPPs on a biennial basis. In 1989, the Commission directed the utilities to offer a common set of full scale DSM programs and submit cost-effectiveness assessment of more aggressive DSM programs by July 1990 (New York PSC, Opinion 89-15). The utilities are given substantial leeway to choose bids that best fit their needs.

Respondent: $\quad$ Sury N. Putta

Title: Principal Policy Analyst

Phone number: $\quad$ 518-474-5368

Address: $\quad$ State of New York

Department of Public Service

Office of Energy Conservation and Environment

Three Empire State Plaza

Albany, NY 12223

(Responses confirmed by mail)

12. Now Yout Public Service Commicsion (NYPSS). May 1984 Opinion No. 84-15. 


\section{State Commission Environmental Externality Survey - North Carolina}

\section{1.) Definition and Role of Environmental Externalities in Planning or Ratemaking by PUCS or other State Agencies}

Currently, there are no regulations governing the incorporation of environmental externalities into the utility planning process.

\section{2.) Roles of Utility Regulatory Agencies in State Utility Regulation and Resource Planning}

The North Carolina Utilities Commission reviews the prudency of utility expenditures, determines appropriate rates of return, and approves new power plant construction, revenue allocation and rate design. Prior to construction of a generating unit in North Carolina, utilities must obtain numerous permits from the North Carolina Department of Environment, Health and Natural Resources. The permits are for a pollutant discharge elimination system, waste water treatment system, ground water monitoring well, dredging and filling, solid and sanitary waste disposal, and an erosion and sediment control plan.

\section{3.) Supply/Demand Balance}

North Carolina generates approximately $35-40 \%$ of its electricity from coal and 50$55 \%$ from nuclear. The state has adequate baseload capacity, but will need additional peaking capacity in five to seven years, which will be met by a combination of pumped storage hydroelectric, combustion turbines, purchases, and other unspecified sources. Peak demand growth is projected to range from $2.0-3.0 \%$ over the next fifteen years.

\section{4.) Resource Planning and Acquisition}

In December, 1988, the Commission set forth guidelines for utilities to submit Least Cost Integrated Resource Plan filings. The plans were filed and have been reviewed by the Public Staff from a data and planning process adequacy standpoint. Hearings are scheduled to begin on January 9,1990, with further guidance from the Commission regarding both current and prospective least cost plans anticipated at that time.

Respondent: James McLawhorn

Title: $\quad$ Engineer, Electric Division

Phone number: $\quad 919-733-2267$ 
Address: Utilities Commission

P.O. Box 29520

Raleigh, NC 27626-0520

(Responses confirmed by mail) 


\section{State Commission Environmental Externality Survey - North Dakota}

\section{1.) Definition and Role of Environmental Externalities in Planning or Ratemaking}

by PUCS or other State Agencies

We know of no current or prospective plans to incorporate environmental externalities into the utility planning process. We are aware that seven of the state's twelve coal plants have scrubbers, but we do not know if the others will have scrubbers installed in response to state or federal legislation.

\section{2.) Roles of Utility Regulatory Agencies in State Utility Regulation and Resource Planning}

The Public Service Commission reviews the prudency of utility expenditures, determines appropriate rates of return, and approves new power plant and transmission line construction, revenue allocation and rate design.

\section{3.) Supply/Demand Balance}

North Dakota generates most of its electricity from coal, but does have $450 \mathrm{MW}$ of hydro. The state has plenty of baseload, but may need additional peak capacity in the near future.

\section{4.) Resource Planning and Acquisition}

The three major utilities file an annual ten year projection of loads and supply-side resources along with a report on their conservation activities. The Commission has ordered utilities to implement least cost-planning.

Respondent: Jerry Lein

Title: $\quad$ Staff Engineer

Phone number: $\quad$ 701-224-4080

Address: $\quad$ North Dakota Public Service Commission

State Capitol

Bismarck, ND 58505-0480

(Responses confirmed by mail) 


\section{State Commission Environmental Externality Survey - Ohio}

\section{1.) Definition and Role of Environmental Externalities in Planning or Ratemaking by PUCS or other State Agencies}

In determining the reasonableness of integrated resource plans, there is a category, separate from the cost analysis, for qualitative consideration of environmental impacts and associated costs. We know of no other current or prospective plans to incorporate environmental externalities into the utility planning process.

\section{2.) Roles of Utility Regulatory Agencies in State Utility Regulation and Resource Planning}

The Public Utilities Commission reviews the prudency of utility expenditures, determines appropriate rates of return, approves revenue allocation and rate design, and determines the reasonableness of the long-term demand forecast and the integrated resource plan to meet that demand. The PUC's rulings on these integrated resource plans serve as the basis for the determination of need for new power plant construction.

The Power Siting Board approves new power plant and gas and electric transmission line construction based on an evaluation of the environmental impacts of the proposed facility and a consideration of the PUC's determination of the need for additional capacity. The Board not only determines the nature of potential environmental impact but determines that the facility has the minimum adverse impact given the nature and economics of alternatives.

\section{3.) Supply/Demand Balance}

Ohio generates approximately $90 \%$ of its electricity from coal and $8 \%$ from nuclear. Some areas of the state need additional peaking capacity and may need more baseload capacity in a few years. Summer peak demand for the state was approximately 26,435 MW in 1989. Twenty year projections submitted to the PUC by utilities show a statewide peak load of approximately $32,991 \mathrm{MW}$ by 2009 , while the PUC staff's independent forecast is for approximately $31,183 \mathrm{MW}$.

\section{4.) Resource Planning and Acquisition}

Since 1983, utilities have been required to submit annual twenty-year forecasts of energy and demand and resource plans to meet the demand. As a benchmark, the PUC staff annually prepares an independent forecast of energy and demand for the state. In 1989 , the PUC adopted rules requiring development of an integrated resource plan to meet the twenty-year forecast of demand. These rules require the utility to assess the expected costs, performance and reliability of all reasonable and practical supply-side and demand- side options available to the utility. The cost-effectiveness of these plans are evaluated by comparing the revenue requirement and rate impacts of the selected plan with those of alternative plans. Integrated resource plans are filed biennially, and formal proceedings are held at least once every five years to review the adequacy of the filings. 
Respondent: Kerry Stroup

Title: Chief, Forecasting Division

Phone number: $\quad$ 614-466-7990

Address: Public Utilities Commission of Ohio

180 East Broad Street

Columbus, OH 43266-0573

(Responses confirmed by mail) 


\section{State Commission Environmental Externality Survey - Oklahoma}

\section{1.) Definition and Role of Environmental Externalities in Planning or Ratemaking by PUCS or other State Agencies}

We know of no current or prospective plans to incorporate environmental externalities into the utility planning process.

\section{2.) Roles of Utility Regulatory Agencies in State Utility Regulation and Resource Planning}

The Oklahoma Corporation Commission reviews the prudency of utility expenditures, determines appropriate rates of return, and approves revenue allocation and rate design. State statutes do not require or authorize prior approval of new power plant construction by the Commission. It would be up to the Commission to raise the issue, if there was a question as to whether the power plant was necessary and belonged in the rate base.

\section{3.) Supply/Demand Balance}

Oklahoma generates approximately half of its electricity from coal and half from gas. The state has an excess of capacity and does not expect to add base or peak power within the next few years. Information on energy and peak demand growth (state or utility) or preferred supply strategies (add new capacity, purchases, QFs, IPPs) is collected from all known sources and reported every two years.

\section{4.) Resource Planning and Acquisition}

Oklahoma does not have an official least cost planning policy, but does have aggressive DSM programs to avoid building new capacity. Bidding was considered several years ago by the Commission, but was not implemented.

Respondent: Glen Gregory

Title: Senior Utility Rate Analyst

Phone number: $\quad 405-521-4467$

Address: Oklahoma Corporation Commission

Jim Thorpe Office Building

Oklahoma City, OK 73105

(Responses confirmed by mail). 


\section{State Commission Environmental Externality Survey - Oregon}

\section{1.) Definition and Role of Environmental Externalities in Planning or Ratemaking by PUCS or other State Agencies.}

The PUC's least cost planning order states that environmental externalities must be recognized in the development of each utility's plan. ${ }^{13}$ Unlike other states where the PUC is responsible for quantifying environmental externality costs, Oregon puts the responsibility on the utilities. Since these costs are uncertain and also subjective, the utilities are required to present these costs separately from conventional accounting costs and to give a range of expected values. This process of valuing environmental externalities is designed to be flexible and open to review. Effects on economic development will not be considered by the PUC.

Pacific Power and Light (PP\&L) was the first utility to file a long-term integrated resource plan under the new order and addressed environmental externalities in the following fashion: 1) included a scenario in its sensitivity analysis in which $\mathrm{CO}_{2}$ emissions from PP\&L's existing and new generating facilities would be reduced by $20 \%$ from 1988 levels by the year 2005. Under this scenario, the utility found that it made sense to promote repowering of existing facilities and acquiring more renewable resources compared to the basecase, and; 2) as a check on the robustness of the relative ranking of resources in individual scenarios, PP\&L added a combustion tax of $10 \mathrm{mill} / \mathrm{s} / \mathrm{kWh}$ to the cost of fossil-fired resources to see if that would alter resource ranking.

Oregon also has a state law that requires development of a strategy to achieve a $20 \%$ reduction in greenhouse gases (based on 1988 levels) by $2005 .{ }^{14}$ The strategy will be part of the Oregon Department of Energy's (ODOE) Biennial Energy Plan in 1991.

\section{2.) Roles of Utility Regulatory Agencies in State Utility Regulation and Resource Planning}

The Public Utility Commission reviews the prudency of utility expenditures, determines appropriate rates of return, and approves revenue allocation and rate design. The Energy Facilities Siting Council (EFSC) approves new power plant construction in the state, and the PUC may intervene in EFSC proceedings. ODOE prepares a biennial energy plan for the state. The plan covers all fuels and is not utility-specific. The recommendations in ODOE's plan are not binding on the PUC or the utilities. New utility resources sited in Oregon would be subject to other regulation (such as Department of Environmental Quality and land use planning requirements), but those agencies have not been active in the PUC's least cost planning process.

13 Oregon Public Utility Commission. April 20, 1989. "Order No, 89-507 Before the Public Utility Commission of Oregon - UM 180," Portland, Oregon.

14 Oregon Senate Bill No. 576, 1989. "An Act Relating to Global Warming; Amends ORS 469.060:" 


\section{3.) Supply/Demand Balance}

The PUC regulates three investor-owned electric utilities, which together serve about 80 percent of customers in the state. Portland General Electric (PGE) and Pacific Power and Light (Pacific) are primarily thermal-based systems; Idaho Power supplies most of its power from hydro resources. With existing resources, PGE and Pacific can meet projected energy loads (medium forecast) until 1994 and 1995, respectively. Idaho Power is expected to be energy-surplus through 2008. Lost opportunity resources and system efficiency improvements are the resources likely to be targeted first.

\section{4.) Resource Planning and Acquisition}

The PUC's least cost planning requirements apply to investor-owned electric and gas utilities operating in the state. Pacific made the first filing in November 1989, and PUC action on the plan is expected in early 1990. The PUC can acknowledge the plan or request modification. Acknowledgment does not guarantee favorable rate-making treatment for resources in the plan. PUC staff is investigating the use of competitive bidding by electric utilities to acquire new resources. A staff recommendation regarding PUC policies or rules for competitive bidding is expected by mid- 1990 .

Respondent: Lee Sparling

Title: $\quad$ Manager, Electric Rates and Planning

Phone number: $\quad$ 503-378-6137

Address: $\quad$ Public Utility Commission of Oregon

Labor \& Industries Bldg

Salem, OR 97310

(Responses confirmed by mail) 


\section{State Commission Environmental Externality Survey - Pennsylvania}

\section{1.) Definition and Role of Environmental Externalities in Planning or Ratemaking by PUCS or other State Agencies}

There is a Public Utility Commission order ${ }^{15}$ that, when evaluating demand management programs with benefit-cost ratios near or less than one, utilities must explicitly consider additional factors such as social or philosophical concerns. How they are to be included is not specified. Some utilities use them qualitatively as part of a screening process within the integrated resource planning framework. There are currently no plans to explicitly incorporate environmental externalities into the utility planning process.

\section{2.) Roles of Utility Regulatory Agencies in State Utility Regulation and Resource Planning}

The Public Utility Commission reviews the prudency of utility expenditures, determines appropriate rates of return, and approves revenue allocation and rate design. The Commission has no authority to approve or disapprove new plant construction. We have no information on the role and jurisdiction of other state agencies in the utility planning process.

\section{3.) Supply/Demand Balance}

In 1988, Pennsylvania utilities generated 127.6 billion kilowatt hours, $66 \%$ attributable to coal and $27 \%$ to nuclear. Planned capacity additions amount to 4,406 megawatts through 2008, including 2,283 megawatts of combustion turbine and combined cycle capacity and 2,123 megawatts of base load coal-fired capacity. The first peaking unit is expected to come on line in 1994 and the next base load unit is tentatively planned for 2002. In the aggregate, Pennsylvania's energy demand is expected to grow at about $1.5 \%$ per year. Non-coincident peak demand is also expected to grow at about $1.5 \%$. Alternate energy activity is forecast to increase from 1,229 on-line megawatts to about 3,800 megawatts by 2008 . Pennsylvania utilities currently project summer reserve margins of between $29 \%$ and $35 \%$.

\section{4.) Resource Planning and Acquisition}

Electric utilities are required to file annual resource plans that evaluate the cost effectiveness of all feasible supply-side and demand-side resource options and integrate

15 Pennsylvania Public Utility Commission, Pennsylvania Bulletin, Vol. 14, No. 50, Saturday, December 15 , 1984. 
them into the preferred plan which should result in the lowest possible cost to the ratepayers without jeopardizing system reliability and integrity. The plan must also provide a forecast of the potential for promoting and ensuring the full utilization of practical and economical energy conservation and load management. Informal sessions may be scheduled for reviewing two-year implementation plans and providing an opportunity for interested parties to participate in the review process. However, the Commission does not have the authority to either accept or reject utilities resource plans. The Commission has recently prepared a report which examines existing regulatory barriers to effective implementation of integrated resource planning. We are now soliciting comments on these issues, including the use of supply-side and demand-side bidding options.

Respondent: Blaine Loper

Title: $\quad$ Chief, Division of Conservation and Load Analysis

Bureau of Conservation, Economics and Energy Planning

Phone number: $\quad 717-783-1373,717-783-3458$ (FAX)

Adöress: Pennsylvania PÜC

P.O. Box 3265

Harrisburgh, PA 17120 


\section{State Commission Environmental Externality Survey - Rhode Island}

\section{1.) Definition and Role of Environmental Externalities in Planning or Ratemaking by PUCS or other State Agencies}

The intent in Rhode Island is to consider externalities in reviewing the utilities' resource plans, which are filed biannually with the PUC. The state's largest utility, Narragansett Electric Company which supplies seventy percent of the state's power, is planning to consider environmental externalities in its 1991 Resource Plan. In addition, the Chairman of the Rhode Island PUC is also chair of the New England Governor's Conference Power Planning Committee Task Force on Energy and Environment, which held a workshop on incorporating environmental externalities into resource planning and which has a goal of attempting to have all the New England states adopt the same methodology.

\section{2.) Roles of Utility Regulatory Agencies in State Utility Regulation and Resource Planning}

The Public Utility Commission reviews the prudency of utility expenditures, determines appropriate rates of return, and approves new power plant construction, revenue allocation and rate design. The Energy Facilities Board, chaired by the PUC chairman, licenses major energy facilities in the state. A current proposal for a generating plant before the Bcard is being assessed with environmental externalities incorporated in the cost accounting.

\section{3.) Supply/Demand Balance}

Rhode Island imports most of its power. Only two utility generating plants are in the state. Two new combined cycle gas-fired units (IPPs) are under construction, and repowering of one of the utility plants is in the planning stage. When completed, these projects will make Rhode Island more than half self-sufficient. There are also a number of small and medium-sized QFs under construction or in planning. The state's primary strategy is aggressive conservation, with gas the fuel of choice for electric generation.

\section{4.) Resource Planning and Acquisition}

Review of the utilities' filed Resource Plans is a least cost planning endeavor.

Respondent: Mary Kilmarx

Title: $\quad$ Director of Energy Policy and Planning 
Phone number: $\quad$ 401-277-3500

Address: $\quad$ Rhode Island Public Utilities Commission

100 Orange Street

Providence, RI 02903 


\section{State Commission Environmental Externality Survey - South Carolina}

\section{1.) Definition and Role of Environinematernalities in Planning or Ratemaking by PUCS or other State Agencies}

The Siting Act in South Carolina protects the environment in the planning and approval process of major generation units and transmission facilities. 'This brings evaluations by the State Wildlife Commission, Water Resources Commission and the Department of Health and Environmental Control to the Public Service Commission for use in the approval process. Items concerning social costs, such as providing jobs, are not an official part of this process, but are very sensitive.

\section{2.) Roles of Utility Regulatory Agencies in State Utility Regulation and Resource Planning}

The Public Service Commission reviews the prudency of utility expenditures, determines appropriate rates of return, and approves new power plant construction, revenue allocation and rate design. The Governor's Energy Office has been involved in some proceedings in the area of avoided cost rates for qualified facilities under PURPA.

\section{3.) Supply/Demand Balance}

South Carolina generates approximately $80 \%$ of its electricity from nuclear and the balance is mainly from coal. The state has sufficient baseload capacity, but expects to need additional peak capacity in the early 1990s. The forecast peak demand growth is 2-2.6\% annually. The presently planned peaking units include pumped storage (under construction) and internal combustion turbines. Load management and conservation methods are actively used to control growth.

\section{4.) Resource Planning and Acquisition}

The Commission has an open docket considering least cost planning. All utilities have filed their proposed plans. The public hearing on this issue should begin by midsummer of 1990 . The role of bidding for new capacity has not been actively considered at this time but will be an element considered under the least cost planning. 
Respondent: William C. Sheely, Jr.

Title: Senior Utilities Rate Analyst

Phone number: 803-737-5115

Address: Public Service Commission of South Carolina

P.O. Drawer 11649

Columbia, SC 29211

(Responses confirmed by mail) 


\section{State Commission Environmental Externality Survey - South Dakota}

\section{1.) Definition and Role of Environmental Externalities in Planning or Ratemaking by PUCS or other State Agencies}

We know of no current or prospective plans to incorporate environmental externalities into the utility planning process.

\section{2.) Roles of Utility Regulatory Agencies in State Utility Regulation and Resource Ylanning}

The Public Utilities Commission reviews the prudency of utility expenditures, determines appropriate rates of return, and approves new power plant construction, revenue allocation and rate design. We have no information on the role and jurisdiction of other state agencies in the utility planning process.

\section{3.) Supply/Demand Balance}

South Dakota generates approximately $70 \%$ of its electricity from coal and most of the balance from hydro. The state needs both base and peak capacity. We have no other information on energy and peak dernand growth (state or utility), anticipated large acquisitions, or preferred supply strategies (add new capacity, purchases, QFs, IPPs).

\section{4.) Resource Planning and Acquisition}

We have no information on current or prospective plans to develop least cost planning or the role of bidding in meeting new capacity needs.

Respondent: Martin C. Bettmann

Title: $\quad$ Staff Engineer

Phone number: $\quad 605-773-3201$

Address: $\quad$ Public Utilities Commission

500 E Capital Ave

Pierre, SD 57501-5070

(Responses confirmed by mail) 


\section{State Commission Environmental Externality Survey - Texas}

\section{1.) Definition and Role of Environmental Externalities in Planning or Ratemaking by PUCS or other State Agencies}

The Texas Public Utility Regulatory Act (PURA) requires the Public Utility Commission of Texas (PUCT or Commission) to consider environmental and aesthetic factors in the certification of new generating units and transmission facilities. In practice, current staffing levels limit the level of detail given to the review.

Generating unit Certificates of Convenience and Necessity (CCNs) must consider environmental externalities during a review of the appropriate power plant technology. (For example, the PUCT is currently considering Texas-New Mexico Power Company's request to build four 150-MW circulating-fluidized-bed units. The Environmental benefits of the technology have been seriously considered.) The Commission staff does not explicitly quantify these effects.

\section{2.) Roles of Utility Regulatory Agencies in State Utility Regulation and Resource Planning}

The PUCT reviews the prudency of utility expenditures, determines appropriate rates of return, establishes revenue allocations, and approves rate design during rate proceedings. The Commission gives CCNs for new power plant and transmission lines after a review of the need, cost, and appropriateness of the technology. The PUCT is the only State agency which conducts electric utility resource planning. Other State agencies consider water and air quality during their review of power plants and transmission lines; however, the PUCT is the only State agency which conducts electric utility resource planning.

\section{3.) Supply/Demand Balance}

Texas generated approximately $46 \%$ of its electricity from natural gas and $43 \%$ from coal in 1987. Currently, and for the next ten years, much of the State has adequate capacity reserves. The exception, TU Electric, (in north-central and western Texas) is building two nuclear units and several peaking units and will require additional base load capacity by 1996 or 1997 . The commission staff prepares and the Commissioners adopt a biennial load and a capacity resource forecast, which contains information on the Commission staff's projected loads and capacity resource additions for 13 major generating service areas in the State. A critique of the utilities' forecasts and plans is provided. In general, the Commission staff advocates greater use of bulk power exchanges (including qualifying facility (QF) power), and increased use of strategic rate design and demandside programs to meet future needs. The PUCT will adopt its 1990-99 forecast in late 1990. 


\section{4.) Resource Planning and Acquisition}

Since 1983, utilities have been required to file biennial ten year load and resource forecasts and energy efficiency plans. The utilities have filed avoided costs through the 1980s. The PUCT has never rejected a utility filing outright. However, filing deficiencies have been the basis for disallowances and rate of return adjustments in rate cases. In addition, the Commission adopts an official State-wide forecast and capacity resource plan which may conflict with utility plans. The official forecast is used in CCN proceedings to determine the need for the proposed facilities.

New generating facilities are approved during a two-step certification process. A Notice of Intent (NOI) requires utilities to justify the appropriateness of the proposed facility compared to alternatives. The $\mathrm{CCN}$ is issued if the Commission finds that the proposed generating facility is required under the service area forecast, is the most economical choice of technology, and that conservation, DSM, and alternative energy sources cannot meet the need.

Utilities are required to justify the cost-effectiveness of demand-side management programs in major rate cases. The adequacy of demand-side programs is examined in CCNs for new generating facilities.

The Commission has rejected a formal bidding process for supply and demand resources in favor of a "competitive negotiation" approach. Avoided costs are established every two years and serve as a ceiling for payment to QFs. Utilities negctiate with cogenerators to obtain favorable contracts. The Commission certifies these contracts and resolves disputes between $\mathrm{QFs}$ and utilities. The reasonableness of the contracts may be assessed later in rate cases.

The commission established a Least Cost Planning Task Force in 1987 to examine proposed rule changes. No meetings have been conducted since mid- 1987.

Respondent: Nat Treadway

Title: Economist, Demand Side Management

Phone number: $\quad 512-458-0310$

Address: $\quad$ Electric Division

Public Utility Commission of Texas

7800 Shoal Creek Blvd.

Suite $400 \mathrm{~N}$

Austin, TX 78757

(Responses confirmed by mail) 


\section{State Commission Environmental Externality Survey - Utah}

\section{1.) Definition and Role of Environmental Externalities in Planning or Ratemaking by PUCS or other State Agencies}

The Utah Public Service Commission has established a Least Cost Planning Docket No. 90-2035-01 for Utah Power/PacifiCorp. PacifiCorp has filed its "Resource and Market Planning Program" which includes consideration of environmental externalities in the utility planning process.

\section{2.) Roles of Utility Regulatory Agencies in State Utility Regulation and Resource Planning}

The Commission has regulatory authority over power plant and transmission construction for investor owned and some publicly owned utilities.

The Commission reviews the prudency of utility expenditures, determines appropriate rates of return, revenue allocation, and rate design. The Utah Bureau of Air Quality also has authority in fossil fueled power plant construction.

\section{3.) Supply/Demand Bulance}

Utah generates most of its electricity from coal, supplemented by a small amount of hydro. No statewide supply/demand balance information has been tabulated. Planning for Utah Power \& Light requirements is integrated with PacifiCorp. In PacifiCorp's current medium load growth scenario, energy shortages will emerge in 1995 and will be met by non-construction options through 2008. In the High Growth Scenario, new plant construction begins in 2003 with growth until then met by non-construction options. Peak capacity constraints are not exceeded on any scenario through 2008. The Company purchases much of its peaking capacity.

\section{4.) Resource Planning and Acquisition}

In the Least Cost Planning docket referenced above, the Commission may consider various demand-side measures and/or competitive bidding in meeting new capacity needs. 
Respondent: James M. Byrne

Title: Commissioner

Phone number: $\quad$ 801-530-6719

Address: Public Service Commission 160 E. 300 South

P.O. Box 45585

Salt Lake City, UT 84145

Respondent: George Compton

Phone number: $\quad 801-530-6950$

Address: Department of Commerce

160 E. 300 South

P.O. Box 45802

Salt Lake City, UT 84145-0802

(Responses confirmed by mail) 


\section{State Commission Environmental Externality Survey - Vermont}

\section{1.) Definition and Role of Environmental Externalities in Planning or Ratemaking by PUCS or other State Agencies}

In accord with the Public Service Board Order of 16 April 1990 in Docket No. 5270 on least cost planning, demand-side resource costs will be discounted by ten percent to reflect the "comparative risk and flexibility" advantages of such resources. Supply-side resources will be increased initially by five percent "to capture costs not already included in the monetized prices of supply sources"; moreover, the Order initiates a rule-making proceeding to further define "adders to represent the cost of environmental externalities."

\section{2.) Roles of Utility Regulatory Agencies in State Utility Regulation and Resource Planning}

The quasi-judicial Public Service Board reviews the prudence of utility expenditures, determines appropriate rates of return, and approves new power plant construction, revenue allocation, and rate design. A separate body, the Department of Public Service (within the state's executive branch) represents ratepayers before the Board and develops a "20-Year Plan" for integrated, least cost planning by electric utilities.

These functions are performed in accordance with a statute that: 1) requires the Board to apply comprehensive environmental protection criteria for the review of any supply additions, criteria that incorporate the rules of Vermont's landmark environmental review statute, Act 250, and; 2) require the utilities to exhaust cost-effective demand-side management opportunities before seeking Board approval for new supply resources.

\section{3.) Supply/Demand Balance}

Vermont receives electricity from a supply mix which consists of approximately 40 percent nuclear, 28 percent hydro, 20 percent coal, and the rest oil, gas and biomass. The state expects to meet future increases in demand for electricity through: 1) comprehensive utility-sponsored demand-side efficiency and conservation programs, 2) modest increases in QFs and IPPs, and; 3) imports where necessary.

\section{4.) Resource Planning and Acquisition}

The Board's least cost planning order was issued in April 1990. It details the appropriate methodology for determining utility supply and demand resource plans. As for QFs and IPPs, the Board has not yet promulgated formal bidding procedures, but has indicated an intent to develop such procedures. However, the state's two largest electric utilities and the Department of Public Service (which has limited authority to purchase 
and resell electric power) have already solicited and recelved proposals for independent power projects.

Respondent: Rick Weston

Title: Utility Analyst

Phone number: $\quad 802-828-2358$

Address: $\quad$ Vermont Public Service Board

120 State St., State Office Bldg.

Montpelier, VT 05602

Respondent: Mike Dworkin

Title: General Counsel

Phone number: $\quad 802-828-2358$

Address: $\quad$ Vermont Public Service Board

120 State St., State Office Building

Montpelier, VT 05602

(Responses confirmed by mail) 


\section{State Commission Environmental Externality Survey - Virginia}

\section{1.) Definition and Role of Environmental Externalities in Planning or Ratemaking by PUCS or other State Agencies}

We know of no current or prospective plans to incorporate environmental externalities into the utility planning process.

\section{2.) Roles of Utility Regulatory Agencies in State Utility Regulation and Resource Planning}

The State Corporation Commission reviews the prudency of utility expenditures, determines appropriate rates of return, and approves new power plant construction, revenue allocation and rate design. The SCC also plays a central role among state agencies in monitoring utility planning.

\section{3.) Supply/Demand Balance}

Virginia generates approximately $65 \%$ of its electricity from coal, $25-30 \%$ from nuclear, and the rest comes from hydro, oil, and gas. The state needs additional baseload and peak capacity.

\section{4.) Resource Planning and Acquisition}

Utilities are required to file resource plans every other year that integrate supplyside and demand-side resources. The Commission can require the utilities to resubmit amended plans.

When they need capacity, utilities in Virginia may use competitive bidding to obtain power from private producers. Virginia Power has issued three solicitations. The Commission has given the utilities flexibility in accounting for non-price factors. We have no other information on current or prospective plans to develop least cost planning or the role of bidding in meeting new capacity needs.

Respondent: $\quad$ Bob Lacy

Title: Utilities Research Manager

Phone number: $\quad 804-786-0050$

Address: $\quad$ VA State Corporation Commission

Division of Economic Research \& Development

Bank and Governor Sts.

Richmond, VA 23209

(Responses confirmed by mail) 


\section{State Commission Environmental Externality Survey - Washington}

\section{1.) Definition and Role of Environmental Externalities in Planning or Ratemaking by PUCS or other State Agencies}

Regulated utilities are required to develop least cost plans, which are defined as plans to meet needs "at the lowest cost to the utility and its ratepayers." Environmental or other externalities are not explicitly addressed, but the term "cost," which is undefined in the rule, could include environmental costs. For example, in the Washington Utilities and Transportation Commission's regulation requiring competitive bidding, evaluation of both supply- and demand-side bids must include "environmental effects including those associated with resources that emit carbon dioxide." Hence, while environmental impacts are, in the rule, denominated as risks rather than costs of a resource, it would appear that a utility could reject or accept a bid based in part on its environmental impacts. Also, the Commission is a member of the Energy Facilities Siting Council, described below.

\section{2.) Roles of Utility Regulatory Agencies in State Utility Regulation and Resource Planning}

The Commission reviews the prudency of utility expenditures, determines appropriate rates of return, revenue allocation and rate design of its three regulated electric utilities and four gas utilities. Oversight by other regulatory bodies includes siting review by environmental agencies and the Energy Facilities Siting Evaluation Council, which has primary jurisdiction over direct environmental impacts associated with a new facility; and municipal or county jurisdiction over publicly-owned utilities. Furthermore, resources managed or acquired by the Bonneville Power Administration in this state must be consistent with the Northwest Power Plan (the region's least cost plan), which may take environmental externalities into account.

\section{3.) Supply/Demand Balance}

Washington State, and the northwest in general, have ample capacity through hydro storage and thermal generation for the foreseeable future. Parts of our state (the Puget Sound region) will be needing new energy resources through conservation or baseload supply in the early '90s. Short-term growth in that region is very high--approximately $5 \%$ annually. However, long-term load forecasts for all regulated electric utilities are in the range of $2 \%$ annual load growth. Forecasts submitted by gas utilities are less sophisticated and shorter term, and generally show little or no forecast growth. Growth in the gas utilities will depend very significantly on whether large new gas generation projects will be successful in bypassing the local distribution companies, and to a lesser extent on the amount of fuel switching on the part of residential water and space heating customers. 


\section{4.) Resource Planning and Acquisition}

In 1987, the Commission passed regulations requiring gas and electric utilities to engage in least cost planning, in consultation with the Commission staff, and with public involvement. Reports must be filed every two years which describe the plans and the actions which have been taken as a result of the plans. There is no formal approval of the plans; however, avoided costs must be consistent with the plans; furthermore, when reviewing a resource acquisition or expenditure for prudency in a rate case, the Commission will take into account its consistency with the plan.

As part of its resource acquisition strategy, a utility must engage in competitive bidding for at least qualifying facilities, IPPs and conservation. Additional resources may be included in the competitive bidding process.

Respondent: Deborah Ross

Title:

Policy Specialist

Phone number: $\quad$ 206-586-1186

Address:

The Washington Utilities and Transportation Commission 1300 S. Evergreen Park Drive SW, Olympia, WA 98504

(Responses confirmed by mail) 


\section{State Commission Environmental Externality Survey - West Virginia}

\section{1.) Definition and Role of Environmental Externalities in Planning or Ratemaking by PUCS or other State Agencies}

We know of no current or prospective plans to incorporate environmental externalities into the utility planning process.

\section{2.) Roles of Utility Regulatory Agencies in State Utility Regulation and Resource Planning}

The Public Service Commission reviews the prudency of utility expenditures, determines appropriate rates of return, and approves new power plant construction, revenue allocation and rate design. We have no information on the role and jurisdiction of other state agencies in the utility planning process.

\section{3.) Supply/Demand Balance}

West Virginia generates almost $100 \%$ of its electricity from coal. The utilities forecast a need for 719 MW of new capacity by 1999.

\section{4.) Resource Planning and Acquisition}

Utilities are required to file an annual report forecasting load and resource capacities for the next ten years. Demand side analysis is not required in the report. We have no information on current or prospective plans to develop least cost planning or the role of bidding in meeting new capacity needs.

Respondent: Earl Melton

Title: Utilities Engineer

Phone number: $\quad 304-340-0392$

Address: $\quad$ Public Service Commission of West Virginia

P.O. Box 812

Charleston, WV 25323

(Responses confirmed by mail) 


\section{State Commission Environmental Externality Survey - Wisconsin}

\section{1.) Definition and Role of Environmental Externalities in Planning or Ratemaking by PUCS or other State Agencies}

In the least cost planning process, the Public Service Commission credits noncombustion technologies because of the impact of reduced air pollution. Demand- and supply-side options for all forecasted capacity are ranked by cost in the planning process. Fifteen percent is then either added to the cost of all combustion technologies or subtracted from non-combustion options. The fifteen percent credit is an interim step intended to capture the costs of some environmental factors that need to be considered during the energy planning process. Work is underway to develop qualitative and quantitative methods which allow comparisons of the environmental and other non-monetary factors for all options in the planning process. This analysis will be required in the next long range planning filing made by the utilities. The utilities are also required to file alternate plans based on major planning goals, such as minimizing $\mathrm{CO}_{2}$ production.

To reduce damage from acid rain, the state legislature passed a bill in 1985 requiring utilities to cut sulfur dioxide emissions to $50 \%$ of the 1980 levels by 1993 . Wiscon* sin also has an environmental impact law (state version of NEPA) that requires the PSC to consider the environmental implications of its decisions. Most of the focus has been on construction projects proposed by utilities.

\section{2.) Roles of Utility Regulatory Agencies in State Utility Regulation and Resource Planning}

The PSC reviews the prudency of utility expenditures, determines appropriate rates of return, and approves long range electric plans, new utility construction, revenue allocation and rate design. Several other state agencies are actively involved in the utility planning process, particularly the Department of Natural Resources and the Wisconsin Energy Bureau (state energy office). These agencies primarily rev ew and provide comments on utility filings and the PSC assessment, and provide testimony. They may become more involved in particular issues as needed.

\section{3.) Supply/Demand Balance}

Wisconsin generates approximately $60 \%$ of its electricity from coal and $30 \%$ from nuclear. Utilities plan to add about $1500 \mathrm{MW}$ of peaking capacity by the mid 1990 s. Non-utility cogenerators and DSM programs are each expected to add several hundred MW of additional resources. 


\section{4.) Resource Planning and Acquisition}

In 1975, Wisconsin passed a Power Plant Siting I aw, which requires utilities to submit a biennial plan which forecasts energy and peak power demands for the next twenty years and construction and transmission plans for the next fifteen years. That law requires that environmental factors be considered in the long range planning process for the utilities.

In their August, 1986 Advance Plan 4 Order, the PSC ordered utilities to submit plans to develop and implement least cost planning. In April, 1989, the PSC issued guidelines as to how least cost plans should be developed. Two aspects of the guidelines are that supply and demand options are ranked by levelized total technical cost per kW and $\mathrm{kWh}$ and that fifteen percent is added to the cost of combustion technologies. A qualitative/quantitative review of externalities for all options and how that analysis is used to develop plans is also required.

Bidding as an institutional option to obtain more supply/demand resources is being examined as a result of the Advance Plan 5 Order. Reports from the utilities are presently being reviewed. Initial results from staff review of the filing indicate that bidding may have more limited potential in Wisconsin than other states because of the well developed planning process in Wisconsin.

Respondent: Anita Sprenger

Title: $\quad$ Administrator, Division of Energy Planning Programs

Phone number: $\quad 608-267-3590$

Address: Wisconsin Public Service Commission 4802 Sheboygan Ave.

P.O. Box 7854

Madison, WI 53707

(Responses confirmed by mail) 


\title{
State Commission Environmental Externality Survey - Wyoming
}

1.) Definition and Role of Environmental Externalities in Planning or Ratemaking by PUCS or other State Agencies

The Wyoming Public Service Commission has started to review environmental externalities, including sulfur oxides and carbon dioxide, for possible incorporation into future regulation.

\section{2.) Roles of Utility Regulatory Agencies in State Utility Regulation and Resource Planning}

The Public Service Commission reviews the prudency of utility expenditures, determines appropriate rates of return, and approves new power plant construction, revenue allocation and rate design. The Commission is also trying to determine what increases in native load may occur if coal prices rise and the state economy experiences a quick boost. This information, integrated with current supply and demand, will step into resource planning.

\section{3.) Supply/Demand Balance}

Wyoming generates approximately $80 \%$ of its electricity from coal and the balance is primarily from hydro. The state has large excesses of capacity and does not expect to add any in the next ten years.

\section{4.) Resource Planning and Acquisition}

The state currently has no least cost planning process. The Commission staff is reviewing bidding processes and experience from other states.

\author{
Respondent: David Walker \\ Title: Supervising Rate Engineer \\ Phone number: $\quad 307-777-7427$ \\ Address: $\quad$ Public Service Commission \\ 700 West 21st St. \\ Cheyenne, WY 82002
}


Respondent: Phil Lehr

Title: Rate Engineer

Phone number: $\quad 307-777-7427$

Address: Public Service Commission

700 West 21st St

Cheyenne, WY 82002

(Responses confirmed by mail) 
Appendix B

Telephone Survey Questionnaire 
Person interviewed

Date

PUC Commission

Division

Telephone ( )

1. Is your staff incorporating externalities into utility regulatory decision-making, in any of the following activity areas?

Briefly describe your progress to date. ${ }^{1}(\mathrm{Y} \mathrm{N} \mathrm{P}=$ Yes/No/Planning to). Who are the PUC staff experts?
a) ratemaking Y N P
b) bidding Y N P
c) long-range planning Y N P
d) research Y N P
e) other?

2. For each activity area identified above in which your staff incorporates (or is working on) externalities, briefly describe the development process which led to this policy or procedure: (Reference a, b, c, d, e)

- origin of concept

- methods used to bring about implementation

- significant problems faced

- factors being included:

environmental

economic

social

political

other

- internal studies or research produced or relied on

- problems still unresolved

- reference documents available

- What's next on your Commission agenda?

1. Preliminary design stage. 2. A definite staff goal. 3. Resolved and an agreement made with the (a) utility(ies). 4. Appears in a Commission Order. 5. Other, explain. 
3. What are your research needs?

- general information/overview of externalities issues

- data on resource impacts

- methods of quantification

- information on policy development

- information on legal aspects

- information on other states' activities (give examples)

Comments on assistance that national (i.e., non-local issues) research assistance could provide you (i.e., ways that NARUC-DOE-EPA could help you).

e.g.

- research program

- periodic information on state, national activities

- white papers

- dedicating expert assistance to PUC's national or regional workshop

- funding for local studies

- information on new technologies for large scale power generation

Any other comments: 

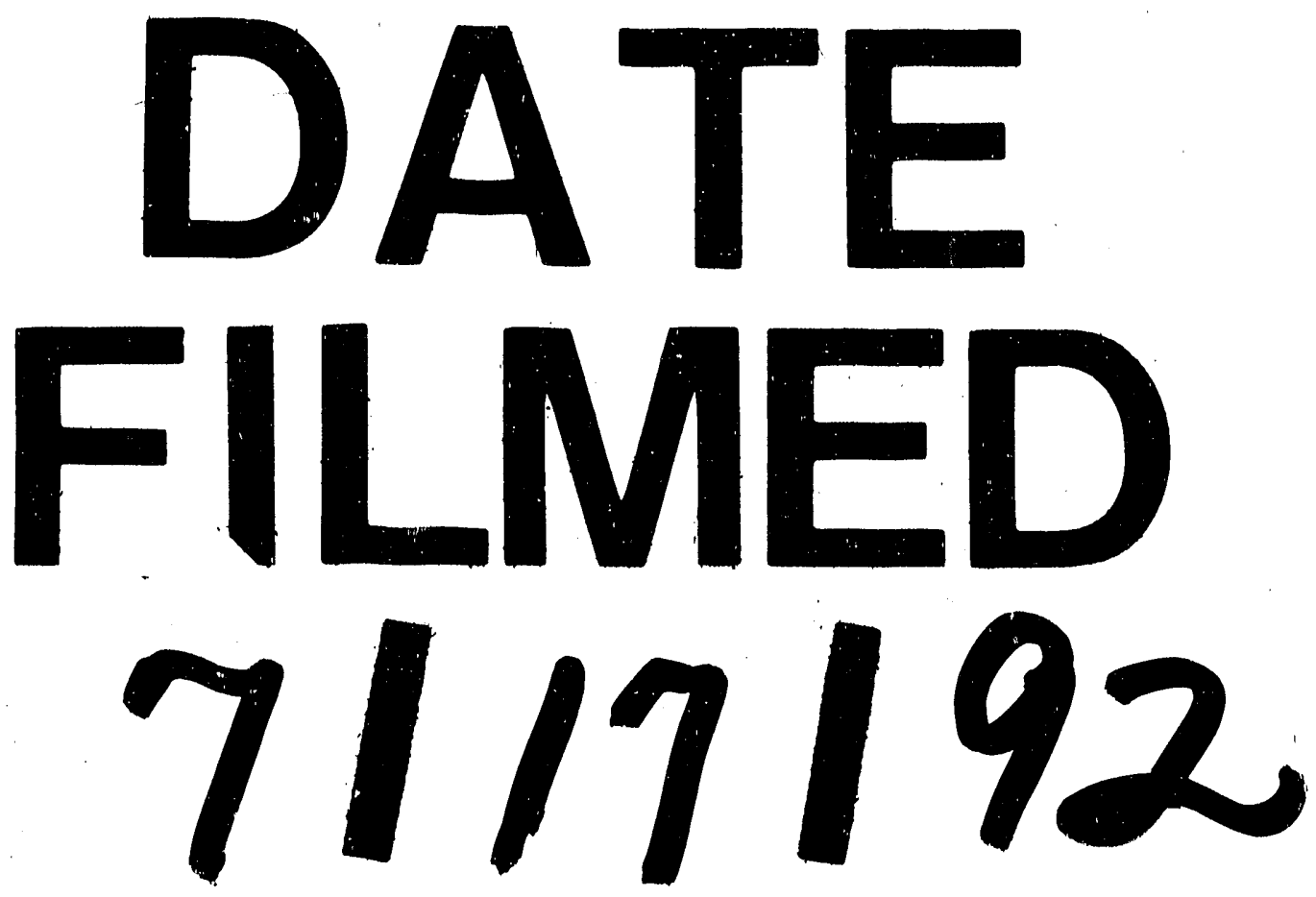